\title{
Genetic characterisation of influenza B viruses detected in Singapore, 2004 to 2009
}

\author{
Muhammad Raihan Jumat ${ }^{1}$, Richard J Sugrue ${ }^{1}$ and Boon-Huan Tan ${ }^{2,3^{*}}$
}

\begin{abstract}
Background: Influenza B viruses are classified into two main lineages: Yamagata-like and Victoria-like, which differ antigenically and phylogenetically. To understand the evolution of influenza B viruses in South East Asia as well as to determine the vaccine efficacy, we genetically characterised gene segments 4, 6 and 8 from non-tissue culture adapted influenza B viruses detected in Singapore from 2004 to 2009.

Methods: VRNA were extracted from the nasopharyngeal swabs or nasal washes of SAF servicemen displaying febrile and respiratory symptoms, and subjected to PCR assay to test for the presence of influenza B virus. The PCR-positive specimens were next subjected to sequencing of the full gene segments 4 (HA), 6 (NA/NB) and 8 (NS1/NEP). The nucleotide sequences were aligned together with that of other specimens isolated from South East Asia as well as the vaccine strains. Phylogenetic trees of each gene segment were constructed and the amino acid alignments were analysed.

Results: A majority of the Singaporean specimens analysed in this study, from 2004-2009, had gene segment 4 from the Victoria-like lineage and gene segment 6 from Yamagata-like lineage. Some of these specimens had both gene segments from the Yamagata lineage and this resulted in several vaccine mismatches. Gene segment 8 from majority of these specimens clustered separately from both the Yamagata and Victoria strains. The HA protein of most of the Singaporean specimens isolated post 2000 contained a glycosylation site at position 211, which was not dominant prior to 2000. No amino acid substitution conferring drug-resistance was found in either the HA or NA proteins.
\end{abstract}

Conclusions: The presence of both lineages co-circulating post 2000, suggests that a trivalent vaccine is not enough to confer immunity to the general public, strongly endorsing the inclusion of both lineages in the vaccine. Several amino acid substitutions were observed, prompting in depth functional analyses.

Keywords: Influenza B, Phylogenetic analysis, Viral evolution, Surveillance, Singapore, Circulating lineage, Vaccine efficiency

\section{Background}

Influenza $\mathrm{B}$ viruses belong to the Orthomyxoviridae family and has a genome of 8 negative, single-stranded segments. Although Influenza B viruses circulates primarily in humans several reports had suggested that seals can serve as a possible animal reservoir for the virus [1-3]. The virus was initially isolated in 1940 [4] and since the

\footnotetext{
* Correspondence: ephtbh@nus.edu.sg

${ }^{2}$ Detection and Diagnostics Laboratory, Defence Medical and Environmental Institute, DSO National Laboratories, 27 Medical Drive, Singapore 117510, Republic of Singapore

${ }^{3}$ Saw Swee Hock School of Public Health, Faculty of Medicine, National University Singapore, Singapore 117549, Republic of Singapore
}

Full list of author information is available at the end of the article early 1980s two distinct lineages have predominated; B/Victoria/2/87-like and B/Yamagata/16/88-like viruses [5,6]. In the 1980s, the Victoria lineage was dominant and this was followed by the Yamagata lineage in the 1990s. Since the year 2000, both lineages have been detected at similar frequencies globally $[7,8]$.

The clinical symptoms associated with influenza B virus infection are generally similar to that of influenza A virus [9-11]. However, a few studies have shown that influenza B infections are linked with severe symptoms [10,12-16]. Throughout 2012, influenza A virus infections dominated the total influenza cases reported globally and regionally by the Global Influenza 
Surveillance Response System (GISRS http://www.who. int/influenza/gisrs_laboratory/en/). Amongst influenza B infections, the GISRS reported that the Victoria-lineage caused more infections that the Yamagata-lineage in 2012 [17]. When analysed separately, the South East Asia region showed that influenza $B$ virus was responsible for more than a third of all influenza infections. At the global level, influenza B viruses accounted for more than half of influenza infections between weeks $4-18$ and 45-52 of 2012 [18]. Majority of these influenza B virus specimens isolated belonged to the Victoria lineage [19].

The two most abundant glycoproteins of influenza B viruses are hemagglutinin (HA) and neuraminidase (NA) [20]. Through the activity of both its subunits, the HA protein functions in receptor binding and in membrane fusion, facilitating viral entry $[20,21]$. Unlike the HA protein, the NA functions late in the viral replication, cleaving the $\alpha-(2,3)$ and $\alpha-(2,6)$ glycosidic links between the terminal sialic acids moieties of glycoproteins, allowing for successful viral shedding [22,23]. Both proteins present as structural epitopes which are recognised by the host immune system [24]. This selective pressure results in these proteins undergoing significant antigenic drift, resulting in antigenic variation from one epidemic to be different from the next. Genetic reassortment of the gene segments occur frequently between the two main influenza B lineages. This means that circulating viruses may have different combinations of gene segments $[25,26]$.
Singapore, being a tropical country, experiences a higher prevalence of influenza viruses than most temperate countries. Its tropical conditions as well as being a commercial hub has allowed for influenza viruses to circulate all year round with peaks between April-July and NovemberJanuary [27-29]. Between the years of 1972-1999, there have been 25 reported influenza epidemics and four of which were caused by influenza B viruses. However, two out of these epidemics had an influenza A strain cocirculating with the predominant influenza B strain [29]. An epidemiological survey of respiratory infections amongst Singaporean military recruits found that up to a third of influenza infections were caused by influenza $B$ infections [30]. The emergence of the pandemic H1N1 of swine origin in 2009 resulted in a suppression of influenza B virus circulation in Singapore. Since 2010, the prevalence of influenza B infections seems almost reciprocal to the prevalence of the influenza A viruses in Singapore [31]. For the past 5 years, a minimum of $20 \%$ of all influenza infections in Singapore were attributed to influenza $B$ viruses [32]. It has been estimated that influenza B infections are responsible for 14.8 out of 100000 deaths in tropical countries yearly [28]. With the current trend in increasing resistance to treatment [33], and with an estimated of 50\% vaccine efficacy in Singapore [34], this number is anticipated to increase.

This study aims to determine the nucleotide sequences of the circulating influenza B virus strains in Singapore

Table 1 Influenza B component of the bi-annual trivalent influenza vaccine (TIV) from 2004-2013

\begin{tabular}{|c|c|c|c|c|}
\hline Year & Hemisphere & Strain & Lineage & Abbreviation \\
\hline $2012-2013$ & Northern & B/Wisconsin/1/2010 & Yamagata & Vacc1213N B Wisconsin 012010 \\
\hline 2012 & Southern & B/Brisbane/60/2008 & Victoria & Vacc0912NS B Brisbane 602008 \\
\hline $2011-2012$ & Northern & B/Brisbane/60/2008 & Victoria & \\
\hline 2011 & Southern & B/Brisbane/60/2008 & Victoria & \\
\hline 2010-2011 & Northern & B/Brisbane/60/2008 & Victoria & \\
\hline 2010 & Southern & B/Brisbane/60/2008 & Victoria & \\
\hline $2009-2010$ & Northern & B/Brisbane/60/2008 & Victoria & \\
\hline 2009 & Southern & B/Florida/4/2006 & Yamagata & Vacc0809NS B Florida 42006 \\
\hline 2008-2009 & Northern & B/Florida/4/2006 & Yamagata & \\
\hline 2008 & Southern & B/Florida/4/2006 & Yamagata & \\
\hline $2007-2008$ & Northern & B/Malaysia/2506/2004 & Victoria & Vacc0608NS B Malaysia 25062004 \\
\hline 2007 & Southern & B/Malaysia/2506/2004 & Victoria & \\
\hline $2006-2007$ & Northern & B/Malaysia/2506/2004 & Victoria & \\
\hline 2006 & Southern & B/Malaysia/2506/2004 & Victoria & \\
\hline 2005-2006 & Northern & B/Jiangsu/10/2003 & Yamagata & Vacc0506N B Jiangsu 102003 \\
\hline 2005 & Southern & B/Shanghai/361/2002 & Yamagata & Vacc0504N 05S B Shanghai 3612002 \\
\hline 2004-2005 & Northern & B/Shanghai/361/2002 & Yamagata & \\
\hline 2004 & Southern & B/Hong Kong/330/2001 & Victoria & Vacc04S B Hong Kong 3302001 \\
\hline
\end{tabular}

The composition of the TIV is recommended bi-annually by the WHO. The influenza B component is often decided by HI inhibition assay of the prevalent influenza $B$ virus currently circulating. The last column of this table lists the abbreviation used for each vaccine strain throughout this report. 


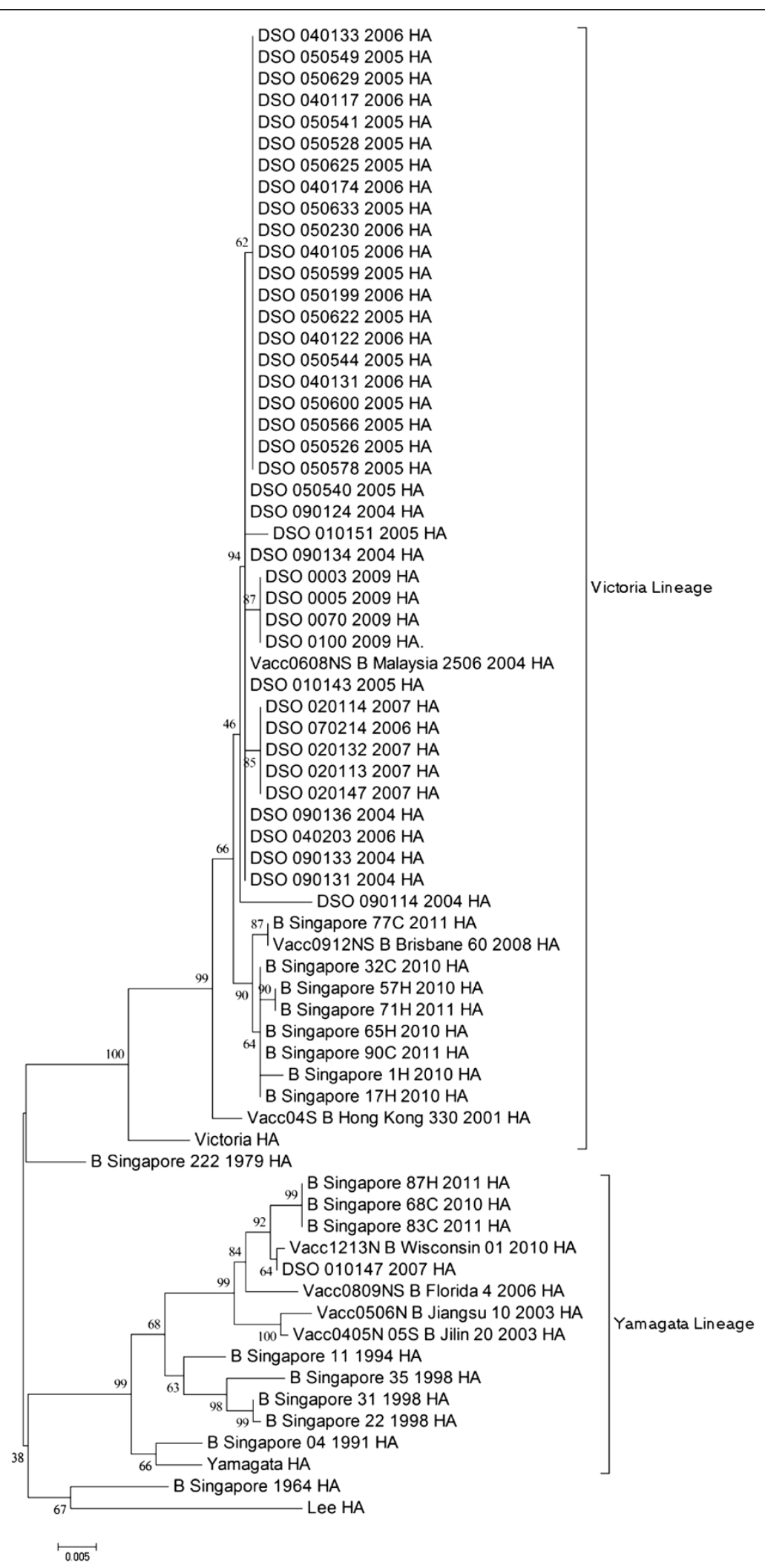

Figure 1 (See legend on next page.) 
(See figure on previous page.)

Figure 1 Phylogenetic tree of the HA gene segment of Singaporean specimens isolated from 2004 to 2009. The HA sequences of these specimens were aligned together with the HA gene segments of B/Lee/40, B/Yamagata/16/88, B/Victoria/2/87, the vaccine strains from 20042013 (Table 1) and the HA gene segments of Singaporean strains isolated in 1964, 1979, 1991, 1994, 1998, 2010 and 2011. Representative strains of influenza B from countries within SEA, such as Hong Kong, Philippines, Taiwan, Thailand, Malaysia and Myanmar, isolated post 2000 available from GenBank were included in this alignment as well. Lineages were marked by the labelled brackets.

between 2004 and 2009 which were not egg/tissue-culture adapted. By comparing the lineage identity of these strains to that of the vaccine strains, we would be able to observe for any mismatches which may result in inadequate immunological protection. Differences in the nucleotide and amino acid sequence would allow us to observe the evolutionary mechanisms of influenza B viruses and understand the divergence of the circulating strains from the vaccine strains. Furthermore, phylogenetic analysis of current and previously sequenced Singaporean strains can allow us to track the reassortment of influenza B virus over the last 50 years. Lastly, analysis of the mutation pattern of these circulating strains may provide greater insights in drug resistance and antibody recognition. We believe that this is the first study to genetically characterise non egg/tissue-culture adapted influenza B virus strains in Singapore. While the samples collected in this study were from the military, it is important to note that a large percentage of Singaporean males are enrolled into the military at the age of 18. This makes the results obtained in this study representative of national surveillance [30].

\section{Results}

\section{Sequence and phylogenetic analysis of gene segments 4 and 6}

Viral RNA (vRNA) was extracted directly from clinical specimens and used as template for PCR amplification and sequencing. A list of all the specimens sequenced in this study can be found in Additional file 1: Table S1. Three overlapping DNA fragments corresponding to the open reading frames of the $\mathrm{HA}$ and NA genes were PCR-amplified and sequenced. The resulting contig was then aligned with the rest of the clinical specimens as well as representative strains from SEA and the vaccine strains of 2004-2013 (Table 1) to produce the phylogenetic trees (Figures 1 and 2). Out of the 46 clinical specimens isolated in this study, the HA gene was sequenced from 42 while the NA gene from 44. The HA gene of the clinical specimens sequenced in this study displayed a similarity of $83.5 \%-99.9 \%$ while that for the NA gene; 84.5\%-99.8\%, when compared amongst themselves.

As shown in Figure 1, the gene segment 4 of the specimens sequenced in this study clustered within the Victoria-like lineage together with other recent Singapore strains, except for DSO_010147_2007. Generally, the specimens clustered according to their year of isolation. The specimen DSO_010147_2007 was isolated in year 2007, but clustered within the Yamagata lineage, together with some of the recent Singapore strains isolated in 2010 and 2011. Figure 2 shows the phylogenetic tree of gene segment 6 of the same specimens and shows that they fall within the Yamagata lineage. Similar to that in Figure 1, most of these specimens clustered according to their year of isolation (Figures 1 and 2).

\section{Sequence and phylogenetic analysis of gene segment 8}

To facilitate future functional analysis, gene segment 8 was sequenced as described in the methods section. The 36 clinical specimens yielding sequence for gene segment 8 in this study displayed $89.8 \%-100 \%$ similarity. A phylogenetic tree of gene segment 8 was generated similarly to gene segments 4 and 6 (Figure 3 ). As reported previously, gene segment 8 of B/Victoria/2/87 and B/Yamagata/16/88 did not split into 2 separate clusters, unlike gene segments 4 and 6, in Figures 1 and 2 [25]. Instead, both strains fell under cluster II, suggesting similar ancestry (Figure 3) [25,35-37]. The majority of the Singaporean specimens clustered in cluster III, together with most of the regional specimens and the vaccine strains. Interestingly, 7 of the specimens isolated in 2004 clustered together with $\mathrm{B} /$ Lee/ 40 in cluster I (Figure 3 ). This is the only instance where a gene segment clusters with B/Lee/40 (Figures 1, 2 and 3).

\section{HA protein sequence analysis}

The main neutralising epitope of HA of the Victoria-like strains lies between residues $178-185$ and this is known as the 'tip' (Table 2) [38]. The amino acid sequence of the specimens sequenced in this study as well as other Singaporean strains of Victoria lineage is identical to $\mathrm{B} /$ Victoria/87. Only two substitutions were observed in the vaccine strains: B/Hong Kong/330/2001 (E179D) and $\mathrm{B} /$ Brisbane/60/2008 (N180K). The 'tip' epitope is not as conserved amongst the Singapore strains of the Yamagata lineage (Table 2). For example, DSO_010147_2007, the only Yamagata-like specimen sequenced in this study has a N181Y substitution which was previously unseen in any sequence but in the vaccine strain B/Wisconsin/01/2010, suggesting that this substitution was newly introduced.

Table 3 lists the variation displayed at the main neutralising epitope of the HA from Yamagata-like strains known as the 'loop', between aa 156-164 [39]. DSO_ 010147_2007 has 2 substitutions in this epitope: V161A and R164K. 


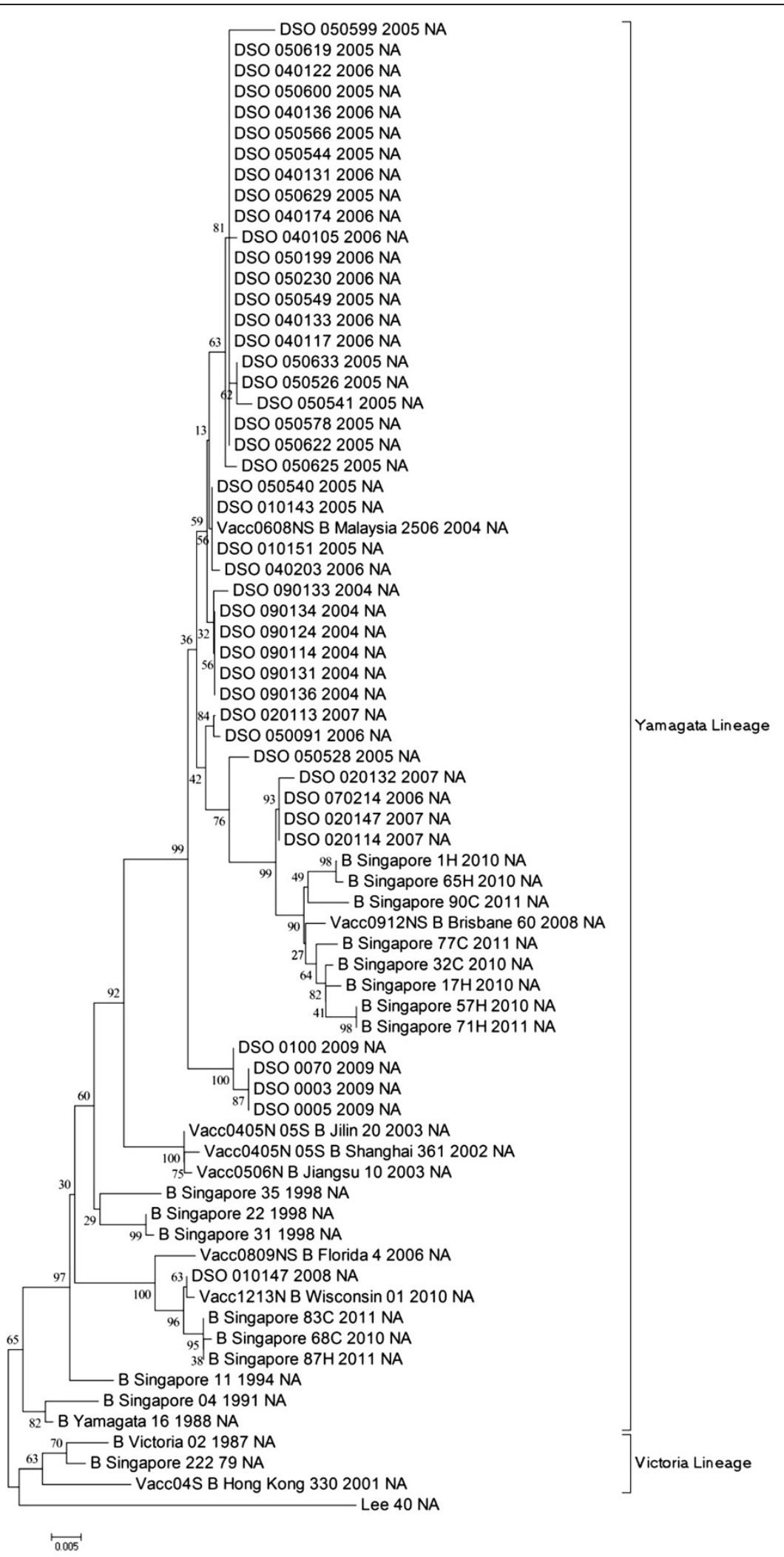

Figure 2 (See legend on next page.) 
(See figure on previous page.)

Figure 2 Phylogenetic tree of the NA gene segment of Singaporean specimens isolated from 2004 to 2009. The NA sequences of these specimens were aligned together with the NA gene segments of B/Lee/40, B/Yamagata/16/88, B/Victoria/2/87, the vaccine strains from 20042013 (Table 1) and the NA gene segments of Singaporean strains isolated in 1979, 1991, 1994, 1998, 2010 and 2011. Representative strains of influenza B from countries within SEA, such as Hong Kong, Philippines, Taiwan, Thailand, Malaysia and Myanmar, isolated post 2000 available from GenBank were included in this alignment as well. Lineages were marked by the labelled brackets.

A glycosylation site at aa 211-213 (NET) was observed in most of the specimens isolated in Japan post 2002. Prior to 2002, aa 211-213 displayed a variety of sequences (NEA, KET, NEN and NET) [40]. Table 4 lists the sequence of the strains analysed in this study. All of the specimens sequenced had this glycosylation site except for DSO_050629_2005 (NEI). Interestingly, the HA gene segment of DSO_050629_2005 belonged to the Victoria lineage and this glycosylation site was initially found only in Japanese strains belonging to the same lineage. The same glycosylation site was observed even in Singaporean specimens isolated in 2010-2011. B/ Singapore/222/1979 and B/Singapore/1964 did not have this glycosylation site (TET and NEI), while, 3 of the 5 Singaporean specimens isolated in the 90s contained the glycosylation site (NKT) sequences.

Three separate epitopes on the HA of influenza B have been identified which are targets of binding of antibodies CR8033, CR8071 and CR9114. These three antibodies were able to provide immunological protection in mice when administered after influenza $B$ viral infection in mice [41]. The epitope recognised by CR8033 exists on the HA trimer, which overlaps the conserved receptor binding site (Table 5). Specimens of Yamagata lineage displayed variability at positions 151, 165, 177, 215 and 218 , while only two specimens of the Victoria lineage showed variability at position 151 . Uniquely, while N165 was conserved in all the Victoria strains, the Yamagata strains listed in Table 5 could harbour an Isoleucine, Serine, Aspartic Acid or a Lysine. Similarly, N218 was conserved in Victoria strains but variability was observed in the Yamagata strains (Serine, Lysine and Threonine) (Table 5). R177 was conserved in Singaporean Yamagata strains isolated between 1991 and 1998, while specimens before and after that period contained a Lysine. Notably, P176, which when substituted to a Glutamic acid resulted to poor susceptibility to CR8033, was conserved in all the specimens listed in Table 5.

A K53E substitution within the CR8071 epitope has been shown to produce mutant viruses with reduced susceptibility to the antibody. This substitution was not observed in any of the specimens listed except that DSO_010151_2005 had an Arginine at this position. This substitution does not result in charge reversal as in $\mathrm{K} 53 \mathrm{E}$ and may not result in any significant antigenic change (Table 6). It has also been noted that strains with a Histidine at position 40 rather than a Tyrosine are not effectively neutralized by CR8071. Antibody CR9114 binds to a conserved region within the stem region of the HA protein of both influenza A and B viruses [41]. Singaporean specimens isolated in 2010 and 2011 of the Yamagata lineage displayed K323R and DSO_050599_2005 of the Victoria lineage, displayed I380V (Table 7).

\section{NA protein sequence analysis}

An important functional site located on the NA protein is the calcium binding site which lies between aa 318-350 [42]. Amino acid substitutions in the calcium binding site are listed in Table 8. Most of the substitutions listed are conservative, (E320D, D329N, and R346S) suggesting a positive selection for this site. For example, E320D is seen in five other specimens, B/Myanmar/M107/2007, B/Myanmar/M254/2007, B/Taiwan/14/2007, B/Taiwan/ 2894/2006 and B/Hong Kong/259/2010. D329 is observed in $\mathrm{B} /$ Malaysia/27127/2004, B/Malaysia/1899839/2007, B/Malaysia/1919534/2008, B/Taiwan/2171/2004 and B/ Taiwan/71523/2007. K343E is observed in three specimens (B/Singapore/68C/2010, B/Singapore/83C/2011 and $\mathrm{B} /$ Singapore/87H/2011). R345S substitution is seen in the rest of the specimens analysed in the NA phylogenetic tree except for B/Bangkok/141/1994 which harboured a Leucine at that same position. Each of the amino acids listed are hydrophilic and are substituted with another hydrophilic residue, except for R345L in B/Bangkok/ $141 / 1994$.

\section{NB protein sequence analysis}

Gene segment 6 encodes for the short, hydrophobic NB protein, of which no function has yet been assigned. All of the amino acid substitutions within aa 19-40, the postulated transmembrane domain, were conservative, keeping this stretch hydrophobic (Table 9) [43-46].

\section{NS1 and NEP protein sequence analysis}

Gene segment 8 encodes 2 proteins: the NS1 and the NEP proteins. The NS1 and NEP proteins of the seven specimens clustering in cluster I show similar amino acid profiles to $\mathrm{B} /$ Lee/40. These amino acid substitutions are not seen in the rest of the clinical specimens clustering in cluster III (Figure 3 and Tables 10 and 11). The nuclear localisation sequence (NLS) of the NS1 protein lies between aa 46-56 [47]. Within the NLS only two amino acid substitutions are observed (H49N and R53K). These 


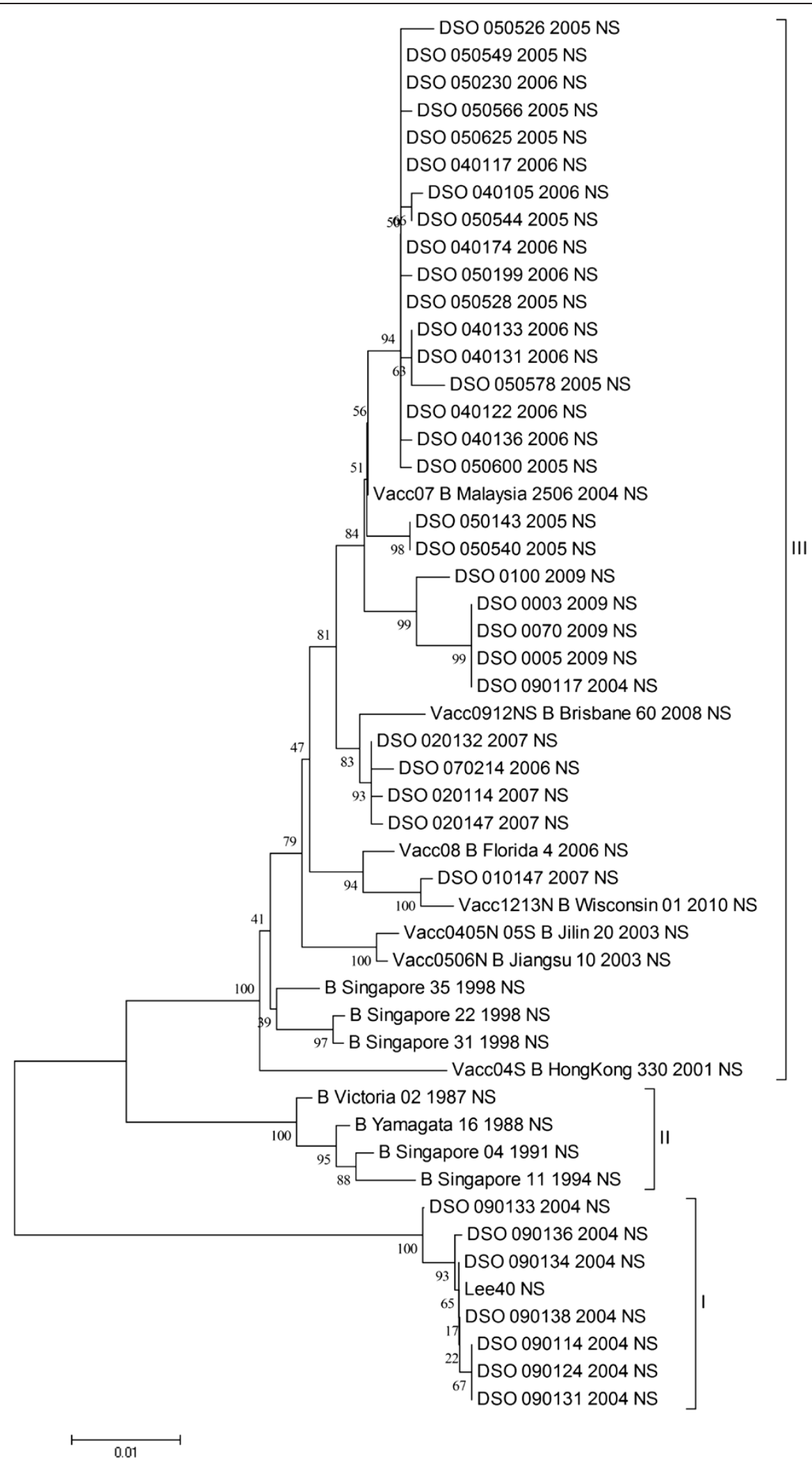

Figure $\mathbf{3}$ (See legend on next page.) 
(See figure on previous page.)

Figure 3 Phylogenetic tree of the NS gene segment of Singaporean specimens isolated from 2004 to 2009. The NS sequences of these specimens were aligned together with the NS gene segments of B/Lee/40, B/Yamagata/16/88, B/Victoria/2/87, the vaccine strains from 20042013 (Table 1) and the NA gene segments of Singaporean strains isolated in 1991, 1994 and 1998. Owing to the lack of NS gene sequences of recent strains from SEA, the NS alignment also included strains from the United States, Egypt and New Zealand which were isolated post 2000. The 3 different clusters of NS1 were labelled Clades I, II and III.

substitutions are only seen in specimens of cluster I (Table 10).

Influenza B NS1 has been shown to bind to and inhibit human ISG15 [48]. 19 amino acids in the first 101 residues of influenza B NS1 have been identified as directly interacting with ISG15 [49]. Out of these 19 amino acids, the specimens sequenced in this study displayed variation at positions 34, 97 and 101 (Table 10). Specimens of cluster I showed sequence identity to B/Lee/40 at these positions. F34L is seen in all the specimens in clades II and III, while I97V is only seen in the 3 specimens listed in Table 10 and in B/Bangkok/141/1994.

Table 2 Amino acid substitution of the HA 'Tip' epitope

\begin{tabular}{|c|c|c|c|c|c|c|c|c|c|}
\hline & & & & $\mathrm{m}$ & gata & 10 & & & \\
\hline & 156 & & & & & & & & 164 \\
\hline Yamagata 88 & G & $\mathrm{S}$ & C & $\mathbf{P}$ & $N$ & v & $\mathrm{T}$ & $S$ & $\mathbf{R}$ \\
\hline DSO 0101472007 & & . & . & & 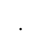 & A & & & K \\
\hline Vacc0405N 05S B Jilin 202003 & . & . & . & . & . & A & & . & K \\
\hline Vacc0506N B Jiangsu 102003 & R & . & & $\cdot$ & . & A & & . & K \\
\hline Vacc0809NS B Florida 42006 & . & . & & . & . & A & & . & K \\
\hline Vacc1213N B Wisconsin 012010 & & . & . & . & . & A & & . & K \\
\hline Singapore 2010-2011 & & . & . & & $\cdot$ & A & & & K \\
\hline B Singapore 041991 & . & . & & . & $\cdot$ & . & & N & . \\
\hline B Singapore 111994 & . & . & & . & & A & & . & . \\
\hline B Singapore 221998 & . & . & & . & . & A & & & K \\
\hline B Singapore 311998 & & & . & & $\cdot$ & A & & & K \\
\hline B Singapore 351998 & . & . & & . & $\cdot$ & A & & . & . \\
\hline B Singapore 2221979 & & . & . & & . & & & N & G \\
\hline B Singapore 1964 & . & & . & . & . & & & N & G \\
\hline Victoria 87 & G & $S$ & C & $\mathbf{P}$ & $\mathbf{N}$ & v & $T$ & $\mathbf{N}$ & G \\
\hline
\end{tabular}

DSO Victoria

DSO 0506292005

Vacc04S B Hong Kong 3302001

Vacc0608NS B Malaysia 25062004

Vacc0912NS B Brisbane 602008

Singapore 2010-2011

Lee40

A

The 'Tip' epitope of the HA protein is the main neutralising epitope of viruses belonging to the Victoria lineage. Specimens listed under B Yamagata 1688 belong to the Yamagata lineage while specimens listed under B Victoria $\mathbf{2} 87$ belong to the Victoria lineage. DSO Victoria: specimens sequenced in this study belonging to the Victoria lineage. Identical amino acids are marked by a dot (.) and deletions are denoted by a dash (-).
E101G is only seen in DSO_050143_2005 and DSO_050540_2005.

\section{Amino acid substitution of the NEP}

Amino acids of positions 35, 66, 80 and 98 of the NEP display sequence variability as listed. I: Specimens clustering in cluster I of the NS phylogenetic tree. II: Specimens clustering in cluster II of the NS phylogenetic tree. III: Specimens clustering in cluster III of the NS phylogenetic tree. Rest of DSO Specimens: rest of specimens sequenced in this study not individually listed in this table. Identical amino acids are marked by a dot (.).

Table 3 Amino acid substitution of the HA 'Loop' epitope

\begin{tabular}{|c|c|c|c|c|c|c|c|c|}
\hline & & & & ctori & a 'ti & & & \\
\hline & 178 & & & & & & & 185 \\
\hline Yamagata 88 & - & D & $\mathbf{N}$ & - & K & $\mathbf{T}$ & A & $\mathbf{T}$ \\
\hline DSO 0101472007 & - & & & Y & & N & & . \\
\hline Vacc0405N 05S B Jilin 202003 & - & . & & . & & $\mathrm{N}$ & & . \\
\hline Vacc0506N B Jiangsu 102003 & - & . & & . & . & $\mathrm{N}$ & & \\
\hline Vacc0809NS B Florida 42006 & - & . & & . & & $\mathrm{N}$ & & \\
\hline Vacc1213N B Wisconsin 012010 & - & . & & Y & & $\mathrm{N}$ & r & . \\
\hline Singapore 2010-2011 & - & & & Y & & $\mathrm{N}$ & & . \\
\hline B Singapore 041991 & - & . & & - & & $\cdot$ & . & \\
\hline B Singapore 111994 & - & . & & $\mathrm{N}$ & & & & \\
\hline B Singapore 221998 & - & . & & N & & & & . \\
\hline B Singapore 311998 & - & & & N & & & & . \\
\hline B Singapore 351998 & - & . & & $\mathrm{N}$ & & . & . & \\
\hline B Singapore 2221979 & - & & - & $\mathrm{N}$ & . & . & . & . \\
\hline B Singapore 1964 & - & $N$ & K & $N$ & & . & $\cdot$ & $\mathrm{R}$ \\
\hline Victoria 87 & $\mathbf{N}$ & D & $\mathbf{N}$ & $\mathbf{N}$ & $\mathrm{K}$ & $\mathbf{T}$ & A & $\mathbf{T}$ \\
\hline
\end{tabular}

DSO Victoria

DSO 0506292005

Vacc04S B Hong Kong 3302001

Vacc0608NS B Malaysia 25062004

Vacc0912NS B Brisbane 602008

Singapore 2010-2011

Lee40

The 'Loop' epitope of the HA protein is the main neutralising epitope of viruses belonging to the Yamagata lineage. Specimens listed under $\mathbf{B}$ Yamagata 1688 belong to the Yamagata lineage while specimens listed under B Victoria $\mathbf{2} \mathbf{8 7}$ belong to the Victoria lineage. DSO Victoria: specimens sequenced in this study belonging to the Victoria lineage. Identical amino acids are marked by a dot (.) and deletions are denoted by a dash (-). 
Table 4 Amino acid substitution of a potential glycosylation site at position 211-213

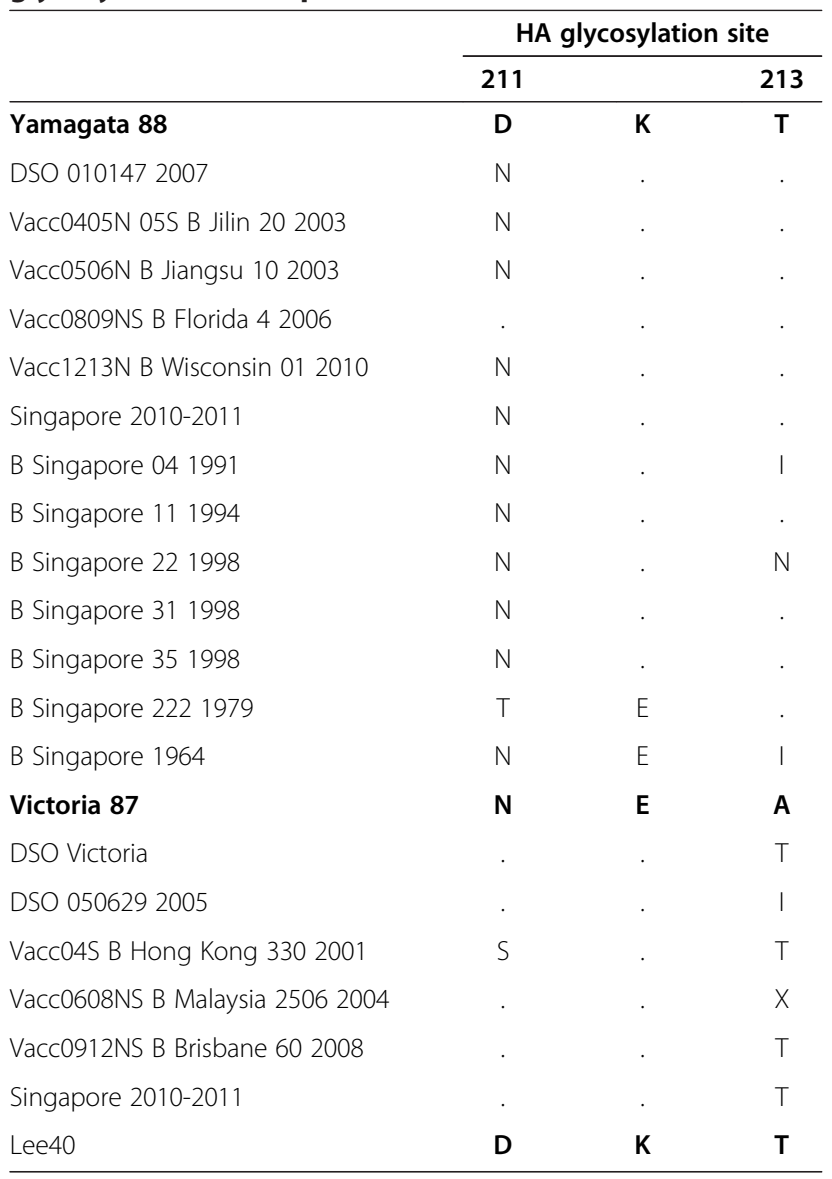

Specimens listed under B Yamagata $16 \mathbf{8 8}$ belong to the Yamagata lineage while specimens listed under $\mathbf{B}$ Victoria $\mathbf{2} \mathbf{8 7}$ belong to the Victoria lineage. DSO Victoria: specimens sequenced in this study belonging to the Victoria lineage. Identical amino acids are marked by a dot (.) and $X$ refers to an unknown amino acid.

Within the NEP protein, the S35N substitution is only seen in the specimens listed in Table 11 as well as B/ Malaysia/33772/2005. While A66 was specific to the cluster I specimens, S80 was also observed in B/Hawaii/11/2004, B/Hawaii/13/2004 and B/Hawaii/33/2004. I98 was also present in B/Bangkok/141/1994 and B/Seoul/1163/2004 (Table 11).

\section{Discussion}

There have been very few studies on influenza B virus epidemiology in Singapore. Among the earliest Singaporean strain sequenced, B/Singapore/1964, had gene segment 4 from the Yamagata lineage. No sequence information of gene segment 4 was available for this strain. Another early strain, B/Singapore/222/1979, had gene segment 4 belonging to the Yamagata lineage and gene segment 7 from the Victoria lineage. The Singaporean specimens isolated in the 1990s had both gene segments belonging to the Yamagata lineage (Figures 1 and 2). Reports of influenza B viruses isolated between 1990 and 1999, have suggested that the dominant lineage of that era (by HI-tests and sequencing of the HA gene alone) were from the Yamagata lineage, with few outbreaks of the Victoria lineage detected in Europe [4,50-53]. The Victoria lineage, however, was suggested to be the emergent stain in 1987 in South China and Japan $[5,26]$.

Post 2004, the majority of the Singaporean specimens had gene segment 4 from the Victoria lineage and gene segment 6 from the Yamagata lineage; however a substantial minority had both gene segments from the Yamagata lineage, such as DSO_010147_2007. In a retrospective study, it was shown that prior to 2002, Yamagata-like viruses were dominant in South East Asia (SEA) [54]. During the year 2002, most of the viruses circulating in the same region were Victoria-like, while post-2002 both lineages have been circulating almost too equal frequencies. This suggests that viruses of the Victoria lineage could have emerged from South China and Japan and managed to spread to Singapore by 2002, as supported by previous studies $[7,8]$.

Vaccine studies in children as well as in laboratory animals had previously showed that the vaccination with the Yamagata lineage of influenza B does not provide immunity against the viruses of the Victoria lineage $[55,56]$. The data from these studies also suggested that post 2000 , influenza B viruses of both lineages were cocirculating simultaneously. This further suggests that including one influenza B strain in the bi-annual trivalent vaccine is clearly insufficient to protect the entire population against influenza B infection. For example, $\mathrm{B} /$ Malaysia/2506/2004, the vaccine strain suggested for 2006-2008, had gene segments 4 and 6 from the Victoria and Yamagata lineages respectively. Viruses of this reassortment order represent the majority of the Singaporean specimens sequenced in this study. However, vaccinated individuals infected with viruses similar to DSO_010147_ 2007 would probably not be protected by the B/Malaysia/ $2506 / 2004$ vaccine. The same case can be argued for the vaccine strain $B /$ Brisbane $/ 60 / 2008$, which is similar in reassortment to B/Malaysia/2506/2004; but 3 out of the 11 Singaporean specimens isolated in 2010-2011 did not match this re-assortment pattern (Figures 1 and 2) further suggesting that the protection from the vaccine strain was not adequate. Similar observation was previously made where $95 \%$ of the influenza viruses circulating in 20072008 were of the Yamagata lineage while the vaccine strain was of the Victoria lineage [57]. In another report, it was shown that between the years 1999-2000, the circulating strains only match the vaccine strains in 5 out of the 10 years period [58]. The data from this study agrees with the latest injunction to include two strains of influenza B viruses in the biannual vaccine so as ensure that the public is adequately immunised by both lineages [58-60]. 
Table 5 Amino acid substitution of the CR8033 epitope

\begin{tabular}{|c|c|c|c|c|c|c|c|c|c|c|c|c|c|}
\hline & & & & & & & $033(\mathrm{H}$ & & & & & & \\
\hline & 154 & 155 & 157 & 165 & 175 & 177 & 178 & 215 & 218 & 219 & 255 & 256 & 258 \\
\hline Yamagata 88 & $T$ & $S$ & $S$ & $\mathrm{~N}$ & v & $\mathbf{R}$ & - & Q & $\mathrm{N}$ & $\mathbf{L}$ & $\mathbf{L}$ & $P$ & $\mathrm{~S}$ \\
\hline DSO 0101472007 & . & . & . & I & . & K & . & . & . & . & . & . & . \\
\hline Vacc0405N 05S B Jilin 202003 & . & . & . & $S$ & . & K & . & $\mathbf{P}$ & . & . & . & . & . \\
\hline Vacc0506N B Jiangsu 102003 & . & . & . & $S$ & . & K & . & . & . & . & . & . & . \\
\hline Vacc0809NS B Florida 42006 & . & . & . & 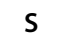 & . & K & . & . & . & . & . & . & . \\
\hline Vacc1213N B Wisconsin 012010 & . & . & . & I & . & K & . & . & $S$ & . & . & . & . \\
\hline Singapore 2010-2011 (Yam) & . & . & . & I & . & K & . & . & . & . & . & . & . \\
\hline B Singapore 041991 & . & . & . & D & . & . & . & . & . & . & . & . & . \\
\hline B Singapore 111994 & . & . & . & $S$ & . & . & . & . & . & . & . & . & . \\
\hline B Singapore 221998 & . & . & . & $S$ & . & . & . & . & . & . & . & . & . \\
\hline B Singapore 311998 & . & . & . & $S$ & . & . & . & . & . & . & . & . & . \\
\hline B Singapore 351998 & . & . & . & $S$ & . & . & . & . & . & . & . & . & . \\
\hline B Singapore 2221979 & . & . & . & $N$ & . & K & . & . & K & . & . & . & . \\
\hline B Singapore 1964 & . & . & . & $\mathbf{K}$ & . & K & . & . & $\mathbf{T}$ & . & . & Q & . \\
\hline Victoria 87 & $\mathbf{T}$ & $S$ & $S$ & $N$ & v & K & $\mathrm{N}$ & Q & $\mathrm{K}$ & $\mathbf{L}$ & L & $\mathbf{P}$ & $\mathrm{S}$ \\
\hline DSO Victoria & . & . & . & . & . & . & . & . & . & . & . & . & . \\
\hline Vacc04S B Hong Kong 3302001 & . & . & . & . & . & . & . & . & . & . & . & . & . \\
\hline Vacc0608NS B Malaysia 25062004 & . & . & . & . & . & . & . & . & . & . & . & . & . \\
\hline Vacc0912NS B Brisbane 602008 & . & . & . & . & . & . & . & . & . & . & . & . & . \\
\hline Singapore 2010-2011 (Vic) & . & $\cdot$ & . & . & . & . & . & . & . & . & . & . & . \\
\hline Lee40 & $\mathbf{T}$ & $S$ & $S$ & $\mathbf{N}$ & I & K & - & Q & $\mathrm{R}$ & $\mathbf{L}$ & $\mathbf{L}$ & K & $S$ \\
\hline
\end{tabular}

Specimens listed under B Yamagata $16 \mathbf{8 8}$ belong to the Yamagata lineage while specimens listed under B Victoria $\mathbf{2} \mathbf{8 7}$ belong to the Victoria lineage. DSO Victoria: specimens sequenced in this study belonging to the Victoria lineage. Identical amino acids are marked by a dot (.) and $\mathrm{X}$ refers to an unknown amino acid.

Gene segment 8 of $\mathrm{B} /$ Victoria/2/87 and B/Yamagata/ $16 / 88$ clustered together in cluster II, suggesting similar ancestry (Figure 3). It is also possible that the split in the lineages occurred before the emergence of these two strains. Evidence for this lies in the clustering pattern of B/Singapore/222/1979 and B/Singapore/1964 in Figures 1 and 2. Both of these specimens were isolated prior to the emergence of the ancestor strains, yet still cluster within the Yamagata or Victoria lineages.

The V161A substitution in the HA protein has not been reported but strains carrying K164 have been shown to have the same reactivity with strains displaying R164. Strains displaying R156 and G164 have been documented with the inability to react with the antibody [39]. Interestingly vaccine strain B/Jiangsu/10/2003 has R156 while B/Singapore/222/1979 and B/Singapore/1964 have G164. Further functional studies will be required to determine if these two substitutions result in a change in antibody binding.

The data from Table 7, pertaining to the glycosylation site at aa 211-213, suggests that position 211 of the HA protein is probably exposed, and located on the exterior of the globular protein. The folding of the protein at this position is also independent of its lineage. All the vaccine strains except for B/Florida/4/2006 and B/Hong Kong/ $330 / 2001$ did not contain this potential glycosylation site. The amino acid at position 213 for B/Malaysia/2506/2004 is unknown, as the codon at that position has the nucleotide sequence ayc (where $\mathrm{y}=\mathrm{c}$ or $\mathrm{t}$ ) therefore is it not possible to determine if this protein has the glycosylation site (Table 7). Further analysis of the specimens used to construct the HA phylogenetic tree revealed that all of the regional specimens contained this potential glycosylation site, except for B/Taiwan/72068/2004 (KKT), B/Taiwan/91061/2005 (SET), B/Taiwan/2894/2006 (DET), B/Taiwan/71523/2007 (SKT), B/Malaysia/1749642/2007 (SET) and B/Hong Kong/310/2004 (KET). It is possible that this glycosylation site originated in Japan prior to its spread worldwide; however since this glycosylation site was also seen in Singapore as early as 1994, it suggests that the origin of this glycosylation site occurred independent to the previous one. Studies in influenza A viruses have led to the suggestion that an introduction of a glycosylation site may mask an antibody-binding epitope, 
Table 6 Amino acid substitution of the CR8071 epitope

\begin{tabular}{|c|c|c|c|c|c|c|c|c|c|c|c|c|c|c|c|c|c|c|}
\hline & \multicolumn{18}{|c|}{ CR8071 (Head) } \\
\hline & 52 & 53 & 55 & 56 & 67 & 73 & 74 & 75 & 76 & 77 & 100 & 101 & 105 & 300 & 301 & 302 & 303 & 305 \\
\hline Yamagata 88 & $\mathbf{T}$ & $\mathrm{K}$ & $\mathrm{H}$ & $F$ & $\mathrm{~K}$ & $\mathrm{~L}$ & $\mathbf{N}$ & $\mathrm{C}$ & $\mathrm{C}$ & $\mathbf{T}$ & $\mathbf{H}$ & $\mathrm{E}$ & v & G & $S$ & L & $\mathbf{P}$ & 1 \\
\hline DSO 0101472007 & . & . & $Y$ & . & . & . & . & . & . & . & . & . & . & . & . & . & . & . \\
\hline Vacc0405N 05S B Jilin 202003 & . & . & $\mathrm{Y}$ & . & . & . & . & . & . & . & . & . & . & . & . & . & . & . \\
\hline Vacc0506N B Jiangsu 102003 & . & $\cdot$ & $\mathrm{Y}$ & . & . & . & . & . & . & . & . & . & . & . & . & . & . & . \\
\hline Vacc0809NS B Florida 42006 & . & $\cdot$ & $\mathrm{Y}$ & . & . & . & . & . & . & . & . & . & . & . & . & . & . & . \\
\hline Vacc1213N B Wisconsin 012010 & . & $\cdot$ & $\mathrm{Y}$ & . & . & . & . & . & . & . & . & . & . & . & . & . & . & . \\
\hline Singapore 2010-2011 & . & . & $Y$ & . & . & . & . & . & . & . & . & . & . & . & . & . & . & . \\
\hline B Singapore 041991 & . & . & $\cdot$ & . & . & . & . & . & . & . & . & . & . & . & . & . & . & . \\
\hline B Singapore 111994 & . & . & $\cdot$ & . & . & . & . & . & . & . & . & . & . & . & . & . & . & . \\
\hline B Singapore 221998 & . & $\cdot$ & $\mathrm{Y}$ & $\cdot$ & . & $\cdot$ & $\cdot$ & $\cdot$ & $\cdot$ & . & . & $\cdot$ & · & · & . & $\cdot$ & $\cdot$ & $\cdot$ \\
\hline B Singapore 311998 & . & . & . & . & . & . & . & . & . & . & . & . & . & . & . & . & . & . \\
\hline B Singapore 351998 & . & $\cdot$ & $\cdot$ & . & . & . & . & . & . & . & . & . & . & . & . & . & . & . \\
\hline B Singapore 2221979 & . & $\cdot$ & $\cdot$ & . & . & . & . & . & $\cdot$ & . & . & . & . & . & . & . & . & . \\
\hline B Singapore 1964 & . & $\cdot$ & . & . & . & . & . & . & . & . & . & . & . & . & . & . & . & . \\
\hline Victoria 87 & $\mathbf{T}$ & $\mathrm{K}$ & $\mathbf{H}$ & $F$ & K & $\mathrm{L}$ & $\mathbf{N}$ & $\mathrm{C}$ & $\mathrm{C}$ & $\mathbf{T}$ & $\mathbf{H}$ & $E$ & v & G & $S$ & $\mathbf{L}$ & $\mathbf{P}$ & I \\
\hline DSO Victoria & . & $\cdot$ & $\cdot$ & . & . & . & . & . & . & . & . & . & . & . & . & . & . & . \\
\hline DSO Victoria 2009 & 1 & $\cdot$ & $\cdot$ & . & . & & . & . & $\cdot$ & . & . & . & . & . & . & . & . & . \\
\hline DSO 0101512005 & . & $\mathbf{R}$ & . & . & . & . & . & . & . & . & . & . & . & . & . & . & . & $\cdot$ \\
\hline DSO 0901142004 & . & $\cdot$ & . & . & . & $\mathrm{F}$ & . & . & . & . & . & . & . & . & . & . & . & . \\
\hline Vacc04S B Hong Kong 3302001 & . & $\cdot$ & $\cdot$ & . & . & . & . & . & $\cdot$ & . & . & . & . & . & . & . & . & . \\
\hline Vacc0608NS B Malaysia 25062004 & . & $\cdot$ & $\cdot$ & . & . & · & . & . & $\cdot$ & . & . & . & . & . & . & . & . & . \\
\hline Vacc0912NS B Brisbane 602008 & . & $\cdot$ & $\cdot$ & . & . & . & . & . & . & . & . & . & . & . & . & . & . & . \\
\hline B Singapore 1H 2010 & . & . & . & . & . & $\mathbf{P}$ & . & . & . & . & . & . & . & . & . & . & . & . \\
\hline B Singapore 17H 2010 & . & $\cdot$ & . & . & . & $P$ & . & . & $\cdot$ & . & . & . & . & . & . & . & . & . \\
\hline B Singapore 32C 2010 & . & $\cdot$ & . & . & $\cdot$ & $\mathbf{P}$ & $\cdot$ & . & $\cdot$ & $\cdot$ & $\cdot$ & . & · & . & . & $\cdot$ & . & $\cdot$ \\
\hline B Singapore 57H 2010 & . & . & . & . & . & $P$ & . & . & $\cdot$ & . & . & . & . & . & . & . & . & . \\
\hline B Singapore 65H 2010 & . & . & . & . & . & $\mathbf{P}$ & . & . & . & . & . & . & . & . & . & . & . & . \\
\hline B Singapore 71H 2010 & . & . & . & . & . & $\mathbf{P}$ & . & . & $\cdot$ & . & . & . & . & . & . & . & . & . \\
\hline B Singapore 77C 2011 & . & . & . & . & . & . & . & . & $\cdot$ & . & . & . & . & . & . & . & . & . \\
\hline B Singapore 90C 2011 & . & . & . & . & . & $\mathbf{P}$ & . & . & . & . & . & . & . & . & . & . & . & . \\
\hline Lee40 & $\mathbf{T}$ & K & $\mathrm{H}$ & $F$ & $\mathrm{~K}$ & $F$ & $\mathbf{N}$ & $\mathrm{C}$ & $\mathrm{C}$ & $\mathbf{T}$ & $\mathbf{H}$ & E & A & G & $S$ & L & $\mathbf{P}$ & 1 \\
\hline
\end{tabular}

Specimens listed under B Yamagata $16 \mathbf{8 8}$ belong to the Yamagata lineage while specimens listed under B Victoria $\mathbf{2} 87$ belong to the Victoria lineage. DSO Victoria: specimens sequenced in this study belonging to the Victoria lineage. Identical amino acids are marked by a dot (.) amino acid.

leading to an antigenic change [61]. This further suggests that a similar masking may take place at this glycosylation position for the influenza $B$ virus HA protein.

The data from Table 6 suggests that CR8071 would be effective in neutralizing current specimens of the Yamagata lineage rather than the Victoria lineage. Position 73 also displayed sequence variability only amongst the specimens of the Victoria lineage, where specimens displayed a Leucine, Phenylalanine or Proline, further investigations have to be carried out to determine if any change in antibody binding would result (Table 6).
Both substitutions listed in Table 7 have not been previously reported but their conservative nature, suggests there might not be any change in antibody binding. This conserved stem region shown in several reports and ours suggests that vaccines eliciting antibodies against such epitopes may provide long lasting protection against both influenza A and B viruses [41,62] (Table 7).

This K343E substitution observed in the NA protein is interesting as it represents a reversal in the charge in a domain which requires conservation of charge for calcium ion binding, as evidenced by their difference in pKa values: 


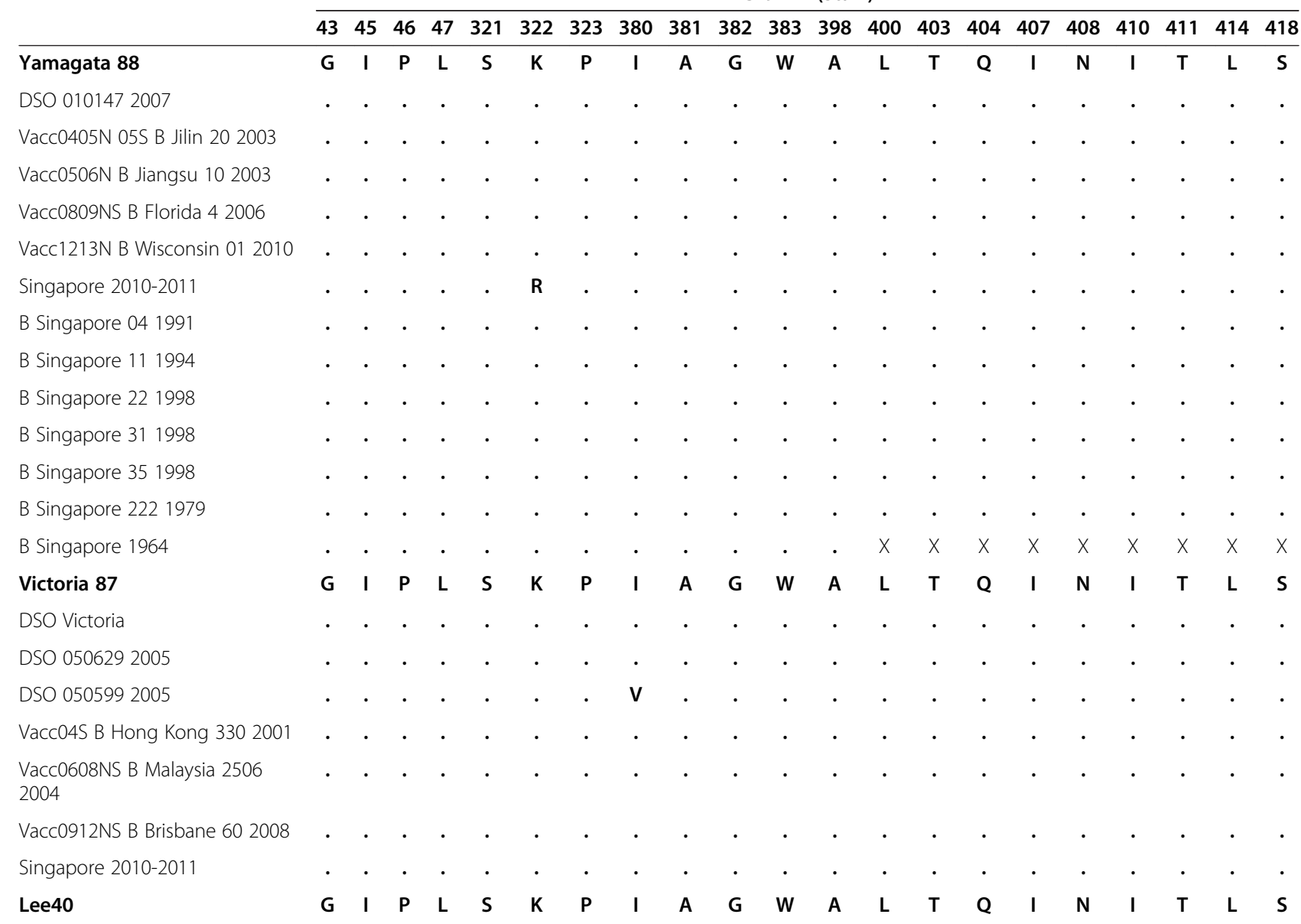

Specimens listed under B Yamagata 1688 belong to the Yamagata lineage while specimens listed under B Victoria $\mathbf{2} \mathbf{8 7}$ belong to the Victoria lineage. DSO Victoria: specimens sequenced in this study belonging to the Victoria lineage. Identical amino acids are marked by a dot (.) and $\mathrm{X}$ information unavailable.

Glutamic Acid-4.07 and Lysine-10.53. This difference in pKa could possibly affect calcium binding. The selection for the calcium binding site of the NA protein to remain hydrophilic strongly suggests conservation of phenotype (Table 8). However, functional and structural assays are needed in order to determine if these substitutions do have an actual effect on calcium binding.

None of the previously cited amino acid changes associated to neuraminidase inhibitor (NAI) resistance were found in this study in either the HA or NA proteins [33,63-72].

While the function of the NB protein is still unknown, aa 19-40 have been shown to constitute its transmembrane domain [43-46]. The data from this study strengthens the view that the function of $\mathrm{NB}$ is membrane-associated since there seems to be a selective pressure in maintaining aa 19-40 hydrophobic (Table 9).

P67S and L92I in the NB were only seen in Singaporean strain isolated in 2009 (Table 9). Neither one of these substitutions occur independently of each other, suggesting that both these amino acids might act in concert in the function of NB.

While R53K in the NS1 protein is conservative, H49N results in the substitution of a basic amino acid to a neutrally charged amino acid (Table 10). This might result in a change in the ability of NS1 to localise to the nucleus. Further functional analysis has to be carried out to determine if the amino acid substitutions listed in Tables 10 and 11 result in a change of NS1 binding to ISG15 or NEP's ability to transport vRNPs out of the nucleus (Tables 10 and 11).

\section{Conclusions}

Phylogenetic analyses of clinical specimens reveal that majority of influenza B strains detected between the years of 2004-2009 were reassortants with gene segments 4 and 6 belonging to the Victoria and Yamagata lineages respectively. This data corroborates with the 
Table 8 Amino acid substitution of the NA calcium binding site

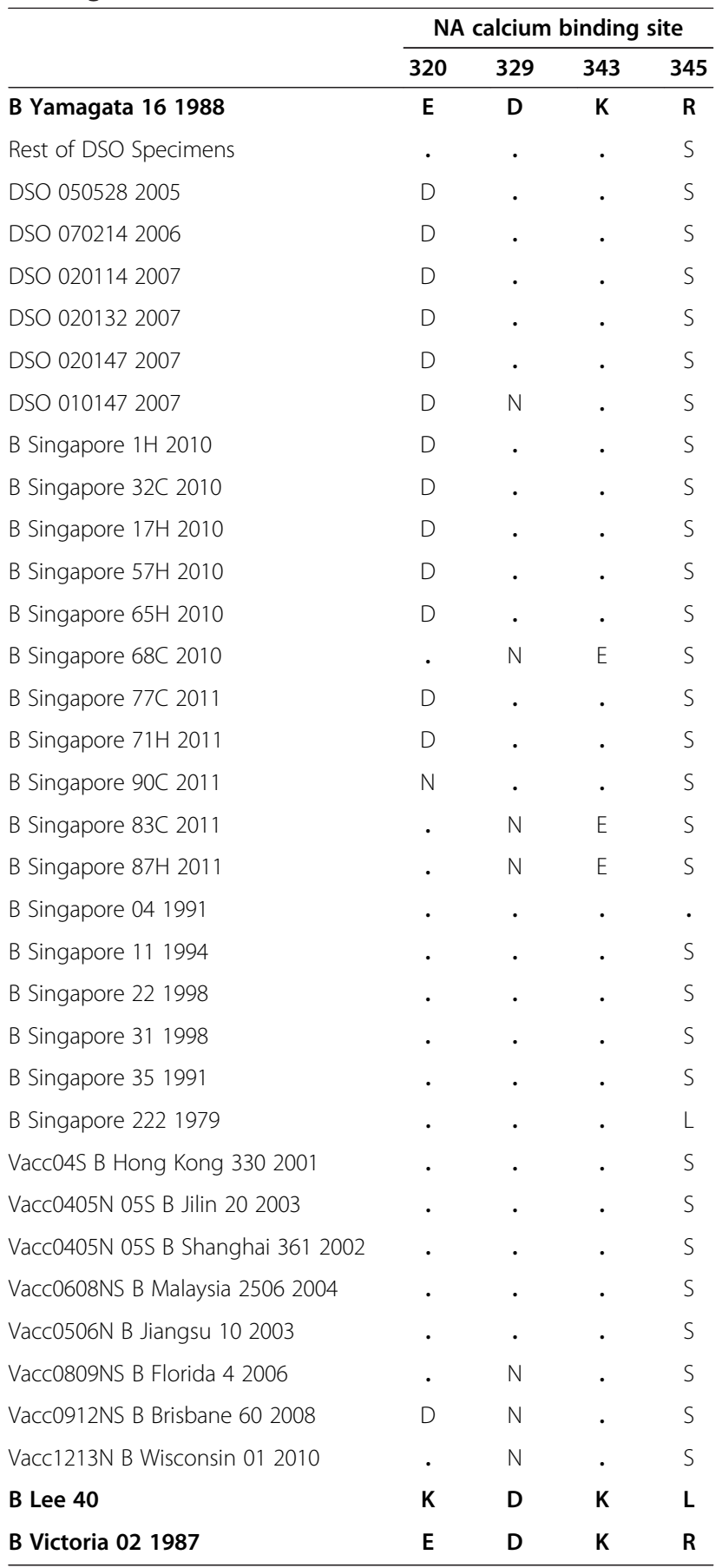

4 amino acid positions within the calcium binding site display variability throughout the NA protein alignment; 320, 329, 343 and 345. Specimens listed under B Yamagata 1688 belong to the Yamagata. Rest of DSO Specimens: rest of specimens sequenced in this study not individually listed in this table. Identical amino acids are marked by a dot (.).

Singaporean specimens isolated in 2010-2011. Several vaccine mismatches were observed in years 2007, 2010 and 2011, strongly proving the need for a quadrivalent vaccine.
The NS1 gene of specimens detected in 2004 show a strong similarity to B/Lee/40 NS1, unseen in other specimens. This phenomenon could suggest that B/Yamagata/ 88 and $\mathrm{B} /$ Victoria/87 are not representative of the split in influenza B evolution and that a third cluster similar to B/ Lee/40 is still in circulation, albeit being a minority.

No amino acid substitution relating to drug resistance has been identified in the specimens sequenced in this study. Other amino acid substitutions highlighted in this study require further functional analysis to determine their ability to affect the protein's phenotype.

We believe, to the best of our knowledge, that this is the first study of influenza B epidemiology in South East Asia to focus on sequence analysis of gene segments 4, 6 and 8 . Gene segments 4 and 6 were chosen as they encode the HA and NA proteins which are the most antigenic proteins of the virus, while gene segment 8 encodes the NS1 protein which is the main protein involved in pathogenesis. The clinical specimens analysed were sequenced directly from VTM and were not passaged through eggs or tissue culture to avoid tissue culture/egg adaptations. This avoids tissue culture/egg adaptations, giving us an accurate representation of the circulating sequences of influenza B viruses.

\section{Methods \\ Virus}

The influenza B virus, strain B/Lee/40 (VR101) was purchased from the American Type Culture Collection (ATCC). The virus was stored in $1 \mathrm{ml}$ aliquots in $-80^{\circ} \mathrm{C}$. 12 day old embryonated chicken eggs were infected with $\mathrm{B} /$ Lee $/ 40$ for 48 hrs at $37^{\circ} \mathrm{C}, 5 \% \mathrm{CO}_{2}$. Allantoic fluid was harvested and clarified at $2000 \mathrm{rpm}$ for $15 \mathrm{~min} .1 \mathrm{ml}$ aliquots of the clarified allantoic fluid were stored in $-80^{\circ} \mathrm{C}$.

\section{Clinical specimens}

Specimens were collected from the Singapore military men who reported sick to the medical centres of various camps between 2004 and 2009. Only individuals presenting a fever of greater than $38^{\circ} \mathrm{C}$ (oral temperature) with cough and/or sore throat were recruited for the study. Consenting patients displaying the abovementioned symptoms provided throat swabs or nasal swabs, which were then re-suspended in viral transport medium (VTM), as previously described [30]. These specimens are named according to the following format; DSO_(numerical code) (year of collection). This study, reference 160D-7/404-3, was approved by the Joint Medical Committee, Research, of the Singapore Armed Forces [30].

\section{Extraction of influenza $B$ virus vRNA}

Viral RNA (vRNA) was extracted using the RNeasy minikit (Qiagen, Inc., Valencia, CA, USA) according to manufacturer's instructions. The extracted vRNA were 
Table 9 Amino acid substitution of the NB protein

\begin{tabular}{|c|c|c|c|c|c|c|c|c|c|c|c|c|}
\hline & & & & mem & ee dc & & & & & Ecto & nain & \\
\hline & 21 & 22 & 24 & 29 & 30 & 31 & 34 & 35 & 43 & 48 & 67 & 92 \\
\hline B Yamagata 161988 & $\mathrm{~V}$ & 1 & $T$ & $F$ & $T$ & $\mathrm{v}$ & $T$ & $\mathrm{v}$ & $F$ & $\mathrm{~N}$ & $P$ & $\overline{\mathrm{L}}$ \\
\hline Rest of DSO Specimens & 1 & . & . & . & I & . & . & 1 & $P$ & Y & . & . \\
\hline DSO 0702142006 & । & . & I & . & । & I & . & । & $\mathrm{L}$ & . & . & . \\
\hline DSO 0500912006 & । & . & I & . & । & I & . & । & $\mathrm{L}$ & . & . & . \\
\hline DSO 0201472007 & । & . & I & . & 1 & I & . & । & L & . & . & . \\
\hline DSO 0201322007 & 1 & . & I & . & I & I & . & I & $\mathrm{L}$ & . & . & . \\
\hline DSO 0201142007 & I & . & I & . & I & I & . & I & $\mathrm{L}$ & . & . & . \\
\hline DSO 0201132007 & I & . & 1 & . & I & I & . & । & $\mathrm{L}$ & . & . & . \\
\hline DSO 0505282005 & I & . & . & . & 1 & . & . & I & $P$ & Y & . & $F$ \\
\hline DSO 00032009 & I & . & . & . & 1 & . & . & 1 & . & Y & $\mathrm{S}$ & 1 \\
\hline DSO 00052009 & । & . & . & . & 1 & . & . & । & . & Y & $S$ & I \\
\hline DSO 00702009 & । & . & . & . & 1 & . & . & । & . & Y & $\mathrm{S}$ & I \\
\hline DSO 01002009 & 1 & . & . & . & 1 & . & . & 1 & . & Y & $\mathrm{S}$ & I \\
\hline B Singapore 041991 & . & $\mathrm{T}$ & . & L & 1 & . & . & $\cdot$ & $L$ & Y & . & . \\
\hline B Singapore 111994 & $A$ & . & . & · & & · & · & $\cdot$ & . & Y & . & . \\
\hline B Singapore 221998 & . & . & . & . & . & . & । & । & . & Y & . & . \\
\hline B Singapore 311998 & . & . & . & . & & . & 1 & 1 & . & Y & . & . \\
\hline B Singapore 351991 & . & . & . & . & & . & . & 1 & . & Y & . & . \\
\hline B Singapore 2221979 & . & . & . & . & & . & . & $\cdot$ & . & Y & . & . \\
\hline Vacc04S B Hong Kong 3302001 & . & . & . & L & & . & . & . & . & . & . & $\mathbf{F}$ \\
\hline Vacc0405N 05S B Jilin 202003 & . & . & . & . & & . & . & । & . & . & . & . \\
\hline Vacc0405N 05S B Shanghai 3612002 & . & . & . & . & & · & · & 1 & . & $\cdot$ & . & . \\
\hline Vacc0608NS B Malaysia 25062004 & 1 & . & . & . & । & • & . & 1 & $\mathbf{P}$ & $\mathrm{Y}$ & . & . \\
\hline Vacc0506N B Jiangsu 102003 & . & . & . & . & & . & . & । & $\cdot$ & $\cdot$ & · & · \\
\hline Vacc0809NS B Florida 42006 & . & . & . & . & 1 & · & . & 1 & . & $\cdot$ & . & . \\
\hline Vacc0912NS B Brisbane 602008 & . & . & . & . & 1 & 1 & · & 1 & $\mathrm{~L}$ & $\cdot$ & . & . \\
\hline Vacc1213N B Wisconsin 012010 & . & . & . & . & । & . & . & । & . & . & . & . \\
\hline B Lee 40 & I & 1 & $\mathbf{T}$ & L & $\mathbf{T}$ & V & 1 & v & $F$ & $\mathbf{N}$ & $\mathbf{P}$ & $\mathbf{L}$ \\
\hline B Victoria 021987 & v & I & $\mathbf{T}$ & $\mathbf{L}$ & 1 & $\mathbf{v}$ & $T$ & v & $F$ & $\mathbf{N}$ & $\mathbf{P}$ & $\mathbf{L}$ \\
\hline
\end{tabular}

Amino acid 21-35 correspond to the putative transmembrane domain of the NB protein while positions 43-92 are located on the ecto domain of the protein. Specimens listed under B Yamagata $\mathbf{1 6} \mathbf{8 8}$ belong to the Yamagata. Rest of DSO Specimens: rest of specimens sequenced in this study not individually listed in this table. Identical amino acids are marked by a dot (.).

stored in $-80^{\circ} \mathrm{C}$ until real-time PCR assays were performed as described in Seah et al., [30]. Only PCR-positive specimens were used for sequencing of the $\mathrm{HA}$ and NA genes.

\section{Primers}

Table 12 lists all the primers used in this study. Primers were designed in-house by the alignment of HA, NA and NS gene segments of influenza B isolated in Singapore previously as available from NCBI database. Primers were designed using BioEdit Software (See Table 13).

\section{cDNA synthesis}

Complementary DNA synthesis was carried out for the specimens using either the Transcriptor First-Strand cDNA synthesis System for RT-PCR (Roche) with the reverse transcription step carried out at $65^{\circ} \mathrm{C}$ for $30 \mathrm{mi}$ nutes or the SuperScript II First-Strand cDNA Synthesis Kit (Invitrogen) with UniB primer (Table 12) [73] and with the reverse transcription step carried out at $42^{\circ} \mathrm{C}$ for 1 hour. Other than the modifications mentioned, all other steps were carried out according to manufacturer's instructions. 
Table 10 Amino acid substitution of the NS1-NLS AND ISG15 binding site

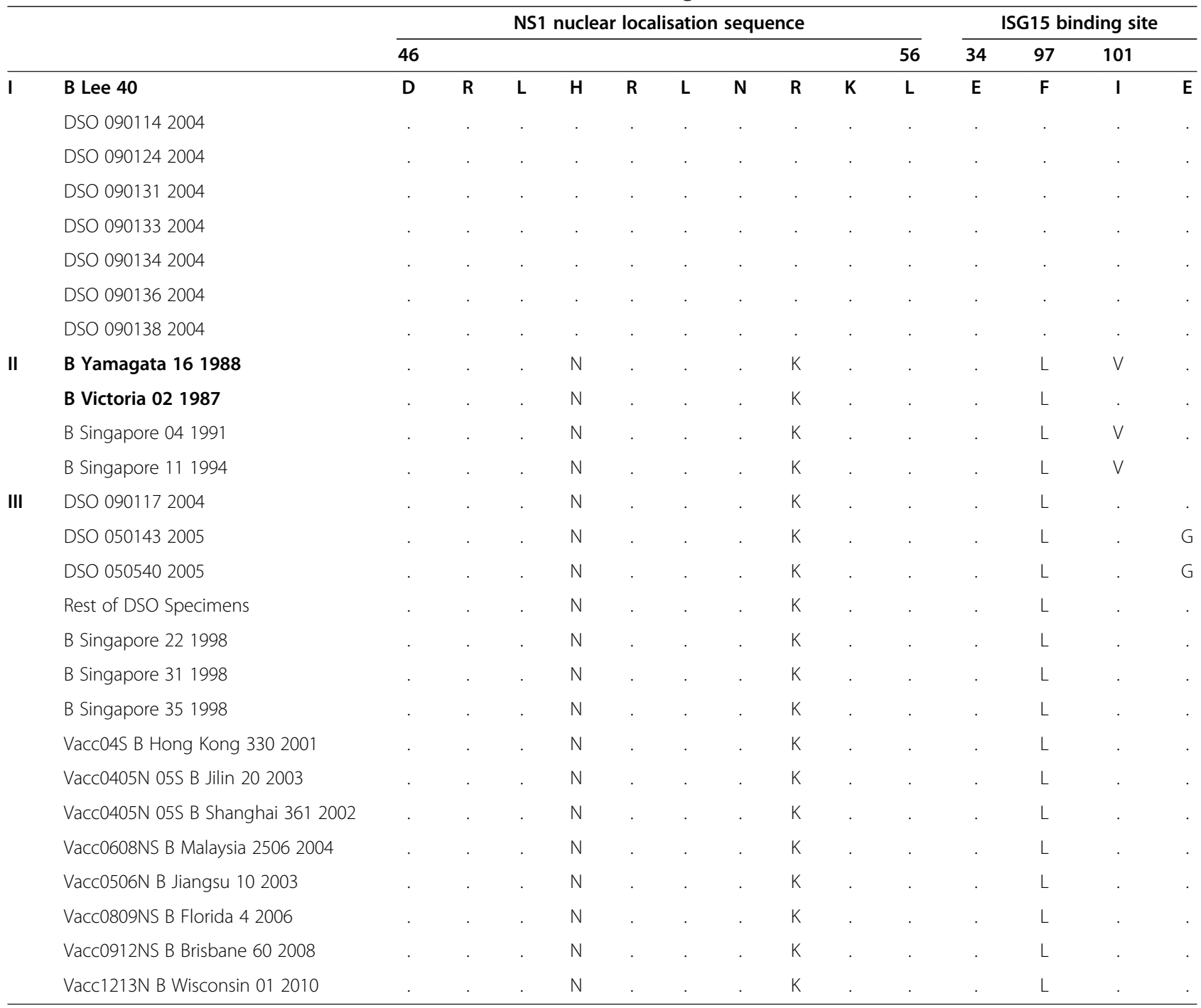

Amino acids 46-56 correspond to the NLS of the NS1 protein. I: Specimens clustering in cluster I of the NS phylogenetic tree. II: Specimens clustering in cluster II of the NS phylogenetic tree. III: Specimens clustering in cluster III of the NS phylogenetic tree. Rest of DSO Specimens: rest of specimens sequenced in this study not individually listed in this table. Identical amino acids are marked by a dot (.).

\section{Hemagglutinin (HA) gene}

The cDNA synthesized from above was used to PCRamplify the full HA gene segment using primers designated HA F and HA R [74] (Table 12) with the Platinum Taq Polymerase High Fidelity kit (Invitrogen) using touchdown PCR thermocycling conditions: initial denaturation at $95 \mathrm{C}$ for 2 minutes, followed by 11 cycles of, $94 \mathrm{C}$ $30 \mathrm{sec}, 55 \mathrm{C}-30 \mathrm{sec}(-1 \mathrm{C} / \mathrm{cycle})$ and $68^{\circ} \mathrm{C}$ for $2 \mathrm{~min}$ and 40 cycles of $94^{\circ} \mathrm{C}-30 \mathrm{sec}, 48^{\circ} \mathrm{C}-\mathrm{sec}, 68^{\circ} \mathrm{C}-2 \mathrm{~min}$, a final extension at $68^{\circ} \mathrm{C}$ for 10 minutes and holding temperature at $4^{\circ} \mathrm{C}$. A second round of PCR was performed to obtain 3 overlapping fragments of the HA gene segment using the primers; HA30F/HA749R, HA471F/HA1169R and HA999/HA1840R (Table 12). The thermocycling conditions for the amplification of all three of these fragments are similar to that described above but with an extension step of $1 \mathrm{~min}$.

\section{Neuraminidase (NA) gene}

The full NA gene was PCR-amplified from cDNAs as described for the full HA gene; except that the primers used were NA F and NA R [74] (Table 1) using the same enzyme and thermocycling conditions described. Again, a second round of PCR was performed to obtain 3 overlapping fragments of the NA gene segment using the primers; NA21F/NA568R, NA361F/NA838R and NA716F/NA1505R (Table 12). The thermocycling conditions for each primer sets required annealing temperatures of $45^{\circ} \mathrm{C}, 58^{\circ} \mathrm{C}$ 
Table 11 Amino acid substitution of the NEP

\begin{tabular}{|c|c|c|c|c|c|}
\hline & & \multicolumn{4}{|c|}{ NEP } \\
\hline & & 35 & 66 & 80 & 98 \\
\hline \multirow[t]{8}{*}{ I } & B Lee 40 & $\mathrm{~S}$ & A & $S$ & I \\
\hline & DSO 0901142004 & . & . & & \\
\hline & DSO 0901242004 & . & . & & \\
\hline & DSO 0901312004 & . & . & . & \\
\hline & DSO 0901332004 & . & . & & \\
\hline & DSO 0901342004 & . & . & & \\
\hline & DSO 0901362004 & & . & . & \\
\hline & DSO 0901382004 & . & . & & \\
\hline \multirow[t]{4}{*}{ II } & B Yamagata 161988 & . & V & $\mathrm{N}$ & \\
\hline & B Victoria 021987 & . & V & $\mathrm{N}$ & \\
\hline & B Singapore 041991 & & V & N & \\
\hline & B Singapore 111994 & . & V & $N$ & \\
\hline \multirow[t]{17}{*}{ III } & DSO 0901172004 & $\mathrm{~N}$ & V & $N$ & V \\
\hline & DSO 00032009 & $\mathrm{~N}$ & V & $N$ & V \\
\hline & DSO 00052009 & $N$ & V & $N$ & V \\
\hline & DSO 00702009 & $N$ & V & $\mathrm{N}$ & V \\
\hline & Rest of DSO Seq & . & V & $N$ & V \\
\hline & B Singapore 221998 & . & V & $N$ & V \\
\hline & B Singapore 311998 & & V & $\mathrm{N}$ & V \\
\hline & B Singapore 351998 & . & V & $N$ & V \\
\hline & B Singapore 041991 & . & V & $N$ & V \\
\hline & Vacc04S B Hong Kong 3302001 & & V & N & V \\
\hline & Vacc0405N 05S B Jilin 202003 & . & V & N & V \\
\hline & Vacc0405N 05S B Shanghai 3612002 & . & V & N & V \\
\hline & Vacc0608NS B Malaysia 25062004 & . & V & N & V \\
\hline & Vacc0506N B Jiangsu 102003 & & V & $\mathrm{N}$ & V \\
\hline & Vacc0809NS B Florida 42006 & . & V & N & V \\
\hline & Vacc0912NS B Brisbane 602008 & & V & N & V \\
\hline & Vacc1213N B Wisconsin 012010 & . & V & $\mathrm{N}$ & V \\
\hline
\end{tabular}

3 amino acids of the NS1 protein (34, 97 and 101) within the ISG15 binding site display variability. I: Specimens clustering in cluster I of the NS phylogenetic tree. II: Specimens clustering in cluster II of the NS phylogenetic tree. III: Specimens clustering in cluster III of the NS phylogenetic tree. Rest of DSO Specimens: rest of specimens sequenced in this study not individually listed in this table. Identical amino acids are marked by a dot (.).

and $50^{\circ} \mathrm{C}$ respectively and all with an elongation time of $1 \mathrm{~min}$.

\section{Non Structural (NS) gene}

The full NS gene segment was amplified from the synthesized cDNA using primers NS F and NS R (Table 12) [74]. The thermocycling conditions required an annealing temperature of $62^{\circ} \mathrm{C}$ and an elongation temperature of $72^{\circ} \mathrm{C}$ for 10 minutes. The NS gene segment was sequenced directly using primers NSF, NSR as well as NS700R and NS376R (Table 12).
Table 12 Primers used in this study

\begin{tabular}{|c|c|c|c|}
\hline $\begin{array}{l}\text { Primer } \\
\text { name }\end{array}$ & 5' Sequence 3' & $\begin{array}{l}\text { Amplicon } \\
\text { size }\end{array}$ & Gene \\
\hline & Diagnostic Primers & & \\
\hline FluB $970 F^{\star}$ & AAATACGGTGGATTAAACAAAAGCAA & $161 \mathrm{bp}$ & HA \\
\hline FluB $1131 R^{\star}$ & AGCTCCGAAGAAACCCCTITCC & & \\
\hline \multirow{2}{*}{$\begin{array}{l}\text { FluB } 1004 \\
\text { Probe }\end{array}$} & CACCCATATTGGGCAATTTCCTATGGC & & \\
\hline & Sequencing Primers & & \\
\hline UniB $^{*}$ & AGC AGA AGC & - & All \\
\hline $\mathrm{HA} 30 \mathrm{~F}^{\S}$ & CTA CTC ATG GTA GTA ACA TCC & $709 \mathrm{bp}$ & $\mathrm{HA}$ \\
\hline $\mathrm{HA} 749 \mathrm{R}^{\S}$ & $\begin{array}{l}\text { YGG GAA GCC ACC AAT CTG } \\
\text { AGA AAC }\end{array}$ & & \\
\hline $\mathrm{HA} 471 \mathrm{~F}^{\S}$ & ACC TCA GGA TCT TGC CCT AAC G & $689 \mathrm{bp}$ & \\
\hline $\mathrm{HA} 1169 \mathrm{R}^{\S}$ & TGT GTA TCC GTG CCA ACC TGC AAT & & \\
\hline HA $999 F^{\S}$ & AAA GCC ATA GGA AAT TGC CCA & $841 \mathrm{bp}$ & \\
\hline $\mathrm{HA} 1840 \mathrm{R}^{\S}$ & TCA ATA ACG TTT CTT TGT AAT & & \\
\hline$H A F^{\perp}$ & $\begin{array}{l}\text { TAT TCG TCT CAG GGA GCA GAA GCA } \\
\text { GAG CAT TIT CTA ATA TC }\end{array}$ & $1840 \mathrm{bp}$ & \\
\hline$H A R^{\perp}$ & $\begin{array}{l}\text { ATA TCG CTC CGT ATT AGT AGT AAC } \\
\text { AAG AGC ATT TाT C }\end{array}$ & & \\
\hline $\mathrm{NA} 21 \mathrm{~F}^{\Delta}$ & GCT ACC TTC AAC TAT ACA AAC G & $547 \mathrm{bp}$ & NA \\
\hline NA $568 R^{\S}$ & TAC CAT CAT GGC ATG CGG A & & \\
\hline NA $361 \mathrm{~F}^{\S}$ & GCT CCC TTG ATA ATA AGG GAA CC & $477 \mathrm{bp}$ & \\
\hline$N A 838 R^{\S}$ & ATG TTC TAC TCT TCC TGT TGG & & \\
\hline$N A 716 F^{\S}$ & GGG GGA RAT TGT TAT CTT ATG & $789 \mathrm{bp}$ & \\
\hline NA $1505 R^{\S}$ & $\begin{array}{l}\prod \prod \text { CAG AAA CAA TTA AKT TCA GTA } \\
\text { AGG }\end{array}$ & & \\
\hline$N A F^{\perp}$ & $\begin{array}{l}\text { TAT TCG TCT CAG GGA GCA GAA } \\
\text { GCA GAG CA }\end{array}$ & $1505 \mathrm{bp}$ & \\
\hline$N A R^{\perp}$ & $\begin{array}{l}\text { ATA TCG CTC CGT ATT AGT AGT } \\
\text { AAC AAG AGC ATT TT }\end{array}$ & & \\
\hline NS $376 R^{\S}$ & CTG GTG TTG AAG GGT AAT & - & NS \\
\hline NS $700 R^{\S}$ & AT CTT CTT CAT CCT CCA CTG TAA & - & \\
\hline$N S F^{\perp}$ & $\begin{array}{l}\text { TAT TCG TCT CAG GGA GCA GAA } \\
\text { GCA GAG GAT TTG TIT AGT C }\end{array}$ & $1053 \mathrm{bp}$ & \\
\hline$N S R^{\perp}$ & $\begin{array}{l}\text { ATA TCG TCT CGT ATT AGT AGT } \\
\text { AAC AAG AGG ATT TIT AT }\end{array}$ & & \\
\hline
\end{tabular}

"Taken from Zou et al., [73].

${ }^{\perp}$ Taken from Hoffmann et al., 2000 [74]

§In-house designed primers.

$\triangle$ Taken from Tsai, 2006 [89].

‘Taken from Krafft et al., 2005 [90].

\section{Sequencing and bioinformatics}

Eluted PCR products were sent to $1^{\text {st }}$ BASE Singapore for sequencing. Each PCR fragment was gel-extracted and purified before subjecting to sequencing using the ABI big dye with the respective PCR primers. The DNA sequences of each fragment were assembled using SeqMan program (DNASTAR). For each of the HA, NA and NS1 genes, the nucleotide sequences were aligned with Clustal W from MegAlign software (DNASTAR) and the 
Table 13 Touchdown PCR thermocycling conditions

\begin{tabular}{|c|c|c|c|c|}
\hline Initial denaturation & & $94^{\circ} \mathrm{C}$ & $2 \min$ & \\
\hline \multirow[t]{3}{*}{ Touchdown } & 11 cycles & $94^{\circ} \mathrm{C}$ & $30 \mathrm{sec}$ & \\
\hline & & $55^{\circ} \mathrm{C}$ & $30 \mathrm{sec}$ & $-1^{\circ} \mathrm{C} /$ cycle \\
\hline & & $68^{\circ} \mathrm{C}$ & $2 \min$ & \\
\hline Denaturation & 40 cycles & $94^{\circ} \mathrm{C}$ & $30 \mathrm{sec}$ & \\
\hline Annealing & & $4 \times 8^{\circ} \mathrm{C}$ & $30 \mathrm{sec}$ & \\
\hline Extension & & $68^{\circ} \mathrm{C}$ & $2 \mathrm{~min}$ & \\
\hline Final extension & & $68^{\circ} \mathrm{C}$ & $10 \mathrm{~min}$ & \\
\hline Holding & & $12^{\circ} \mathrm{C}$ & forever & \\
\hline
\end{tabular}

All the PCR conditions in this study are touchdown PCR, with adjustments to the annealing temperatures, and extension times.

phylogenetic trees were next generated using the Neighbour-Joining algorithm. The number of bootstrap replications was set to 1000 and bootstrap values were labelled on the tree branches [75]. The same software was used to locate the positions of the correct open reading frames (ORFs) and the amino acid sequences were next translated. Sequence analysis was performed with closely related sequences obtained with the NCBI blast search, and the vaccine strains for years 2004-2013 [9,76-88] (Tables 7 and 8 ).

\section{Availability of supporting data}

The nucleotide and translated amino acid sequences supporting the phylogenetic trees in this study have been included in the GenBank repository [http://www.ncbi. nlm.nih.gov/genbank] and the following accession numbers have been assigned GU943154-GU943235, KC844161KC844196. The phylogenetic trees generated for this study have also been uploaded to the TreeBase repository with a submission ID of 16558 [http://purl.org/phylo/treebase/ phylows/study/TB2:S16558].

\section{Additional file}

Additional file 1: Table S1. Total of 46 clinical specimens included in this study and their genes which have been sequenced. * Specimens which gave sequence information for all three genes. (Y): Yamagata Lineage, (V): Victoria Lineage, (I): Clade I, (III): Clade III.

\section{Competing interests}

The authors declare that they have no competing interests.

\section{Authors' contributions}

MRJ carried out the experiments. TBH and MRJ analysed the data and wrote the manuscript. TBH and RJS planned the experiments. All authors read and agreed on this manuscript.

\section{Authors' information}

TBH is head of the Diagnostics and Detection Laboratory (DDL) of DSO National Laboratories (Singapore). RJS is Head of Division of the Division of Molecular Genetics \& Cell Biology of the School of Biological Sciences, Nanyang Technological University. MRJ is a PhD student at the School of Biological Sciences, Nanyang Technological University.

\section{Acknowledgments}

We would like to thank DSO National Laboratories for providing the clinical specimens as well as the funding for this project. MRJ is a recipient of the NTU Post-Graduate Scholarship (Ministry of Education, Singapore).

\section{Author details \\ ${ }^{1}$ Division of Molecular and Cell Biology, School of Biological Sciences, Nanyang Technological University, Singapore 637551, Republic of Singapore. ${ }^{2}$ Detection and Diagnostics Laboratory, Defence Medical and Environmental Institute, DSO National Laboratories, 27 Medical Drive, Singapore 117510, Republic of Singapore. ${ }^{3}$ Saw Swee Hock School of Public Health, Faculty of Medicine, National University Singapore, Singapore 117549, Republic of Singapore.}

Received: 12 August 2014 Accepted: 21 November 2014 Published: 1 December 2014

\section{References}

1. Osterhaus AD, Rimmelzwaan GF, Martina BE, Bestebroer TM, Fouchier RA: Influenza B Virus in Seals. Science 2000, 288:1051-1053.

2. Sridharan H, Zhao C, Krug RM: Species specificity of the NS1 protein of influenza $B$ virus: It binds only human and non-human primate ubiquitin-like ISG15 proteins. J Biol Chem 2010, 285(11):7852-7856.

3. Murphy BR, Webster RG: Virology, B.N. Fields et al.; 1990.

4. Nerome R, Hiromoto Y, Sugita S, Tanabe N, Ishida M, Matsumoto M, Lindstrom SE, Takahashi T, Nerome K: Evolutionary characteristics of influenza B virus since its first isolation in 1940: dynamic circulation of deletion and insertion mechanism. Arch Virol 1998, 143:1569-1583.

5. Rota PA, Wallis TR, Harmon MW, Rota JS, Kendal AP, Nerome K: Cocirculation of two distinct evolutionary lineages of influenza type B virus since 1983. Virology 1990, 175:59-68.

6. Kanegae Y, Sugita S, Endo A, Ishida M, Senya S, Osako K, Nerome K, Oya A: Evolutionary pattern of the hemagglutinin gene of influenza $B$ viruses isolated in Japan: cocirculating lineages in the same epidemic season. J Virol 1990, 64:2860-2865.

7. Chi XS, Bolar TV, Zhao P, Rappaport R, Cheng S-M: Cocirculation and evolution of two lineages of influenza $B$ viruses in Europe and Israel in the 2001-2002 season. J Clin Microbiol 2003, 41:5770-5773.

8. Chi XS, Hu A, Bolar TV, Al-Rimawi W, Zhao P, Tam JS, Rappaport R, Cheng S-M: Detection and characterization of new influenza $B$ virus variants in 2002. J Clin Microbiol 2005, 43:2345-2349.

9. WHO: Recommended composition of influenza virus vaccines for use in the 2009-2010 northern hemisphere influenza season; 2009.

10. Derlet RW: Influenza. In eMedicine Infectious Diseases; 2010.

11. Wright P, Neumann G, Kawaoka Y: Orthomyxoviruses. In Fields Virology. 5th edition; 2006:1691-1740.

12. Kim YH, Kim HS, Cho SH, Seo SH: Influenza B virus causes milder pathogenesis and weaker inflammatory responses in ferrets than influenza A virus. Viral Immunol 2009, 22:423-430.

13. William BB, James PL, Stanley MM: Severe illness with influenza B. Am J Med 1980, 68:181-189.

14. Wright PF, Bryant JD, Karzon DT: Comparison of influenza B/Hong Kong virus infections among infants, children, and young adults. J Infect Dis 1980, 141:430-435.

15. Michael KF, John CP, Kevin EB, Robert J, Pamela KH: Epidemic influenza myopathy in Cincinnati in 1977. J Pediatr 1980, 96:545-551.

16. Wu C-T, Hsia S-H, Huang J-L: Influenza B-associated rhabdomyolysis in Taiwanese children. Acta Pædiatrica 2010, 99:1701-1704.

17. GISRS WHO: Global circulation of influenza viruses. 2013. http://gamapserver.who.int/gareports/Default.aspx?ReportNo=6.

18. GISRS WHO: Influenza Laboratory Surveillance Information by GISRS. Influenza Transmission zone: South East Asia. 2013. http://gamapserver. who.int/gareports/Default.aspx?ReportNo=4\&ITZRegion=.

19. GISRS WHO: Percentage of respiratory specimens that tested positive for influenza by influenza transmission zone. Status as of week 51 16-22 December 2012. 2013. http://www.who.int/influenza/surveillance_ monitoring/updates/2013_01_07_influenza_update_176_week_51_main.jpg.

20. Fields BN, Knipe DM, Howley PM: Fields' virology. 5th edition. Philadelphia: Wolters Kluwer Health/Lippincott Williams \& Wilkins; 2007.

21. Earp L, Delos S, Park H, White J: The many mechanisms of viral membrane fusion proteins. Curr Top Microbiol Immunol 2005, 25-66. 
22. Palese $P$, Compans RW: Inhibition of influenza virus replication in tissue culture by 2-deoxy-2,3-dehydro-N-trifluoroacetylneuraminic acid (FANA): mechanism of action. J Gen Virol 1976, 33:159-163.

23. Palese P, Tobita K, Ueda M, Compans RW: Characterization of temperature sensitive influenza virus mutants defective in neuraminidase. Virology 1974, 61:397-410.

24. Quan F-S, Kim M-C, Lee B-J, Song J-M, Compans RW, Kang S-M: Influenza M1 VLPs containing neuraminidase induce heterosubtypic cross-protection. Virology 2012, 430:127-135.

25. McCullers JA, Saito T, Iverson AR: Multiple genotypes of influenza B virus circulated between 1979 and 2003. J Virol 2004, 78:12817-12828.

26. McCullers JA, Wang GC, He S, Webster RG: Reassortment and insertion-deletion are strategies for the evolution of influenza $B$ viruses in nature. J Virol 1999, 73:7343-7348.

27. Doraisingham: Influenza surveillance in Singapore: 1972-86. Bull World Health Organisat 1988, 66:7.

28. Chow SM, Ai Ee L, Suok Kai C: Influenza-associated deaths in tropical Singapore. Emerg Infect Dis 2006, 12:8.

29. Lee VJ, Yap J, Ong JBS, Chan K-P, Lin RTP, Chan SP, Goh KT, Leo Y-S, Chen MIC: Influenza excess mortality from 1950-2000 in tropical Singapore. PLoS One 2009, 4:e8096.

30. Seah SG-K, Lim EA-S, Kok-Yong S, Liaw JC-W, Lee V, Kammerer P, Metzgar D, Russell KL, Tan B-H: Viral agents responsible for febrile respiratory illnesses among military recruits training in tropical Singapore. 2010. In Press, Corrected Proof.

31. Communicable Diseases Division MS: Weekly infectious disease bulletin, epidemiological week 30, 22-28 June 2012. CDC, Ministry of Health, Singapore 2012, 9(30). https://www.moh.gov.sg/content/dam/moh_web/ Statistics/Infectious_Diseases_Bulletin/2012/July/2012_week_30.pdf.

32. MOH S: Weekly infectious disease bulletin. CDC Ministry of Health, Singapore 2014 11(11). https://www.moh.gov.sg/content/dam/moh_web/ Statistics/Infectious_Diseases_Bulletin/2014/March/2014_week_11.pdf.

33. Hatakeyama S, Sugaya $N$, Ito M, Yamazaki M, Ichikawa M, Kimura K, Kiso M, Shimizu H, Kawakami C, Koike K, Mitamura K, Kawaoka Y: Emergence of influenza $B$ viruses with reduced sensitivity to neuraminidase inhibitors. JAMA 2007, 297:1435-1442.

34. Ng TP, Pwee KH, Niti M, Goh LG: Influenza in Singapore: assessing the burden of illness in the community. Ann Acad Med Singapore 2002, 31:182-188.

35. Luo C, Morishita T, Satou K, Tateno Y, Nakajima K, Nobusawa E: Evolutionary pattern of influenza $B$ viruses based on the HA and NS genes during 1940 to 1999: origin of the NS genes after 1997. Arch Virol 1999, 144:1881-1891.

36. Abed Y, Coulthart MB, Li Y, Boivin G: Evolution of surface and nonstructural-1 genes of influenza $B$ viruses isolated in the province of Québec, Canada, during the 1998-2001 period. Virus Genes 2003, 27:125-135.

37. Matsuzaki Y, Sugawara K, Takashita E, Muraki Y, Hongo S, Katsushima N, Mizuta K, Nishimura H: Genetic diversity of influenza B virus: the frequent reassortment and cocirculation of the genetically distinct reassortant viruses in a community. J Med Virol 2004, 74:132-140.

38. Nakagawa N, Suzuoki J, Kubota R, Kobatake S, Okuno Y: Discovery of the neutralizing epitope common to influenza B virus Victoria group isolates in Japan. J Clin Microbiol 2006, 44:1564-1566.

39. Nakagawa N, Kubota R, Okuno Y: Variation of the conserved neutralizing epitope in influenza B virus Victoria group isolates in Japan. J Clin Microbiol 2005, 43:4212-4214

40. Nakagawa N, Kubota R, Maeda A, Okuno Y: Influenza B virus Victoria group with a new glycosylation site was epidemic in Japan in the 2002-2003 season. J Clin Microbiol 2004, 42:3295-3297.

41. Dreyfus C, Laursen NS, Kwaks T, Zuijdgeest D, Khayat R, Ekiert DC, Lee JH, Metlagel Z, Bujny MV, Jongeneelen M, van der Vlugt R, Lamrani M, Korse HJ, Geelen E, Sahin Ö, Sieuwerts M, Brakenhoff JP, Vogels R, Li OT, Poon LL, Pieris M, Koudstaal W, Ward AB, Wilson IA, Goudsmit J, Friesen RH: Highly conserved protective epitopes on influenza B viruses. Science 2012 , 337:1343-1348.

42. Burmeister WP, Ruigrok RW, Cusack S: The 2.2 A resolution crystal structure of influenza $B$ neuraminidase and its complex with sialic acid. EMBO J 1992, 11:49-56.

43. Fischer WB, Pitkeathly M, Sansom MSP: Amantadine blocks channel activity of the transmembrane segment of the NB protein from influenza B. Eur Biophys J 2001, 30:416-420.
44. Fischer WB, Pitkeathly M, Wallace BA, Forrest LR, Smith GR, Sansom MSP: Transmembrane peptide NB of influenza B: a simulation, structure, and conductance studyt. Biochemistry 2000, 39:12708-12716.

45. Betakova T, Nermut MV, Hay AJ: The NB protein is an integral component of the membrane of influenza B virus. J Gen Virol 1996, 77:2689-2694.

46. Hatta M, Kawaoka Y: The NB protein of influenza B virus is not necessary for virus replication in vitro. J Virol 2003, 77:6050-6054.

47. Schneider J, Dauber B, Melen K, Julkunen I, Wolff T: Analysis of influenza B virus NS1 protein trafficking reveals a novel interaction with nuclear speckle domains. J Virol 2009, 83:701-711.

48. Yuan W, Krug RM: Influenza B virus NS1 protein inhibits conjugation of the interferon (IFN)-induced ubiquitin-like ISG15 protein. EMBO J 2001, 20:362-371.

49. Guan R, Ma L-C, Leonard PG, Amer BR, Sridharan H, Zhao C, Krug RM, Montelione GT: Structural basis for the sequence-specific recognition of human ISG15 by the NS1 protein of influenza B virus. Proc Natl Acad Sci 2011, 108(33):13468-13473.

50. CDC: Update: influenza activity-United States and world-wide, May-September 2001. MMWR Morb Mortal Wkly Rep 2001, 50:4.

51. Nakagawa KR, Maeda A, Nakagawa T, Okuno Y: Heterogeneity of influenza $B$ virus strains in one epidemic season differentiated by monoclonal antibodies and nucleotide sequences. J Clin Microbio/ 2000, 38:3.

52. WHO: Recommended composition of influenza virus vaccines for use in the 1999-2000 season. Wkly Epidemiol Rec 1999, 7:5.

53. WHO: Recommended COmposition of influenza virus vaccines for use in the 2002-2003 season. Wkly Epidemiol Rec 2002, 77:5.

54. Barr IG, Komadina N, Durrant C, Sjogren H, Hurt AC, Shaw RP: Circulation and antigenic drift in human influenza $B$ viruses in SE Asia and Oceania since 2000. Commun Dis Intell 2006, 30:350-357.

55. Levandowski RA, Regnery HL, Staton E, Burgess BG, Williams MS, Groothuis JR: Antibody responses to influenza B viruses in immunologically unprimed children. Pediatrics 1991, 88:1031-1036.

56. Rota PA, Hemphill ML, Whistler T, Regnery HL, Kendal AP: Antigenic and genetic characterization of the haemagglutinins of recent cocirculating strains of influenza B virus. J Gen Virol 1992, 73:2737-2742.

57. CDC: Influenza activity-United States and worldwide, 2007-08 season. MMWR Morb Mortal Wkly Rep 2008, 57:692-697.

58. Belshe RB: The need for quadrivalent vaccine against seasonal influenza. Vaccine 2010, 28(Supplement 4):D45-D53.

59. Reed C, Meltzer Ml, Finelli L, Fiore A: Public health impact of including two lineages of influenza $B$ in a quadrivalent seasonal influenza vaccine. Vaccine 2012, 30(11):1993-1998.

60. Ambrose CS, Levin MJ: The rationale for quadrivalent influenza vaccines. Hum Vaccin Immunotherapeutics 2012, 8:81-88.

61. Schulze IT: Effects of glycosylation on the properties and functions of influenza virus hemagglutinin. J Infect Dis 1997, 176:S24-S28.

62. Pica N, Palese P: Toward a universal influenza virus vaccine: prospects and challenges. Annu Rev Med 2013, 64:189-202.

63. Gubareva LV: Molecular mechanisms of influenza virus resistance to neuraminidase inhibitors. Virus Res 2004, 103:199-203.

64. Gubareva Larisa V, Matrosovich Mikhail N, Brenner Malcolm K, Bethell Richard C, Webster Robert G: Evidence for zanamivir resistance in an immunocompromised child infected with influenza B virus. J Infect Dis 1998, 178:1257-1262.

65. Staschke KA, Colacino JM, Baxter AJ, Air GM, Bansal A, Hornback WJ, Munroe JE, Laver WG: Molecular basis for the resistance of influenza viruses to 4-Guanidino-Neu5Ac2en. Virology 1995, 214:642-646.

66. Barnett JM, Cadman A, Burrell FM, Madar SH, Lewis AP, Tisdale M, Bethell R: In vitro selection and characterisation of influenza B/Beijing/1/ 87 isolates with altered susceptibility to zanamivir. Virology 1999, 265:286-295.

67. McKimm-Breschkin J, Trivedi T, Hampson A, Hay A, Klimov A, Tashiro M, Hayden F, Zambon M: Neuraminidase sequence analysis and susceptibilities of influenza virus clinical isolates to zanamivir and oseltamivir. Antimicrob Agents Chemother 2003, 47:2264-2272.

68. McKimm-Breschkin $\mathrm{J}$ : Resistance of influenza viruses to neuraminidase inhibitors - a review. Antiviral Res 2000, 47:1-17.

69. Cheam AL, Barr I, Mosse J, Hampson A, Hurt A: Characterisation of an influenza $B$ variant selected with the neuraminidase inhibitor zanamivir. Int Congr Ser 2004, 1263:122-125. 
70. Cheam AL, Barr IG, Hampson AW, Mosse J, Hurt AC: In vitro generation and characterisation of an influenza $B$ variant with reduced sensitivity to neuraminidase inhibitors. Antiviral Res 2004, 63:177-181.

71. Mishin VP, Hayden FG, Gubareva LV: Susceptibilities of antiviral-resistant influenza viruses to novel neuraminidase inhibitors. Antimicrob Agents Chemother 2005, 49:4515-4520.

72. Hurt AC, lannello P, Jachno K, Komadina N, Hampson AW, Barr IG, McKimm-Breschkin JL: Neuraminidase inhibitor-resistant and -sensitive influenza B viruses isolated from an untreated human patient. Antimicrob Agents Chemother 2006, 50:1872-1874.

73. Zou S: A practical approach to genetic screening for influenza virus variants. J Clin Microbiol 1997, 35:2623-2627.

74. Hoffmann E, Mahmood K, Yang C-F, Webster RG, Greenberg HB, Kemble G: Rescue of influenza B virus from eight plasmids. Proc Natl Acad Sci U S A 2002, 99:11411-11416.

75. Thompson JD, Higgins DG, Gibson TJ: CLUSTAL W: improving the sensitivity of progressive multiple sequence alignment through sequence weighting, position-specific gap penalties and weight matrix choice. Nucleic Acids Res 1994, 22:4673-4680.

76. WHO: Recommended composition of influenza virus vaccines for use in the 2004 influenza season. Wkly Epidemiol Rec 2003, 78:375-379.

77. WHO: Recommended composition of influenza virus vaccines for use in the 2004-2005 influenza season. Wkly Epidemiol Rec 2004, 79:88-92.

78. WHO: Recommended composition of influenza virus vaccines for use in the 2005 influenza season. Wkly Epidemiol Rec 2004, 79:369-373.

79. WHO: Recommended composition of influenza virus vaccines for use in the 2005-2006 influenza season. Wkly Epidemiol Rec 2005, 80:71-75.

80. WHO: Recommended composition of influenza virus vaccines for use in the 2006 influenza season. Wkly Epidemiol Rec 2005, 80:342-347.

81. WHO: Recommended composition of influenza virus vaccines for use in the 2006-2007 influenza season. Wkly Epidemiol Rec 2006, 81:82-86.

82. WHO: Recommended composition of the $2006 / 07$ influenza vaccine. Euro Surveill 2006, 11:E060330-060332.

83. WHO: Recommended composition of influenza virus vaccines for use in the 2007 influenza season. Wkly Epidemiol Rec 2006, 81:390-395.

84. WHO: Recommended composition of influenza virus vaccines for use in the 2008 influenza season. Wkly Epidemiol Rec 2007, 82:351-356.

85. WHO: Recommended composition of influenza virus vaccines for use in the 2007-2008 influenza season. Wkly Epidemiol Rec 2007, 82:69-74.

86. WHO: Recommended composition of influenza virus vaccines for use in the 2008-2009 influenza season. Wkly Epidemiol Rec 2008, 83:81-87.

87. WHO: Recommended composition of influenza vaccines for use in the 2012 southern hemisphere influenza season. Wkly Epidemiol Rec 2011, 86:457-468.

88. WHO: Recommended composition of influenza virus vaccines for use in the 2012-2013 northern hemisphere influenza season. Wkly Epidemio/ Rec 2012, 87:83-95.

89. Tsai H-P, Wang H-C, Kiang D, Huang S-W, Kuo P-H, Liu C-C, Su I-J, Wang J-R: Increasing appearance of reassortant influenza $B$ virus in Taiwan from 2002 to 2005. J Clin Microbiol 2006, 44:2705-2713.

90. Krafft AE, Russell KL, Hawksworth AW, McCall S, Irvine M, Daum LT, Connoly $J \mathrm{~L}$, Reid AH, Gaydos JC, Taubenberger JK: Evaluation of PCR testing of ethanol-fixed nasal swab specimens as an augmented surveillance strategy for influenza virus and adenovirus identification. J Clin Microbiol 2005, 43:1768-1775.

\section{doi:10.1186/1756-0500-7-863}

Cite this article as: Jumat et al:: Genetic characterisation of influenza B viruses detected in Singapore, 2004 to 2009. BMC Research Notes 2014 7:863.

\section{Submit your next manuscript to BioMed Central and take full advantage of:}

- Convenient online submission

- Thorough peer review

- No space constraints or color figure charges

- Immediate publication on acceptance

- Inclusion in PubMed, CAS, Scopus and Google Scholar

- Research which is freely available for redistribution

Submit your manuscript at www.biomedcentral.com/submit
C Biomed Central 